\title{
Geologia Estrutural na previsão e contenção de queda de blocos em encostas: aplicação no Granito Santos, SP
}

\author{
Alexandre Mathias Pinotti \\ Geólogo pelo Curso de Graduação em Geologia, \\ Instituto de Geociências, Universidade Estadual de \\ Campinas, Campinas, SP. \\ pinotti.alexandre@gmail.com \\ Celso Dal Ré Carneiro \\ Departamento de Geociências Aplicadas ao Ensino, \\ Instituto de Geociências, Universidade Estadual de \\ Campinas, Campinas, SP. \\ cedrec@ige unicamp.br
}

\begin{abstract}
STRUCTURAL GEOLOGYFOR PREVENTION OF ROCKFALL ON SLOPES:APPLICATION IN THE SANTOS GRANITE, SP. Anthropogenic actions such as cutting, deforestation and/or overloading can affect the stability of natural slopes. This synthesis describes the main Structural Geology techniques for prediction of landslides and rockfalls on hillsides and rocky slopes. The analytical methods for evaluating slope seek for potential risk situations and to minimize the risk oflandslides and rockfalls. It is necessary to know the massif properties, as lithological composition, degree of weathering and consistency of rocks, and types of discontinuities. We have evaluated the results of a survey carried out on a slope between Santos and São Vicente, SP, with rappelling techniques. There, a consulting firm has recognized the major systems of fractures, and identified blocks in unstable situations, recommending the eventual removal or stabilization. Nowadays, the geological-structural studies stress out the importance of exfoliation joints as features that can promote, due to the progressive weathering and rock breakdown, the formation of slabs and gradual loosening of rock mass down the slope. Citation: Pinotti A.M., Carneiro C.D.R. 2013. Geologia Estrutural para contenção de queda de blocos e análise de estabilidade de encostas: aplicação no granito Santos, Sp. Terræ Didatica, 9(1):132-168. <http://www.ige.unicamp.br/terraedidatica/>.
\end{abstract}

KEYWORDS: Geological structures, Structural Geology, landslides and rockfalls on hillsides, teaching-learning, 3D structures, structural representations.

RESUMO É bem conhecido que ações antrópicas, como cortes, desmatamentos e adição de cargas podem afetar a estabilidade de encostas. $O$ artigo sintetiza as principais abordagens de Geologia Estrutural para previsão e contenção de queda de blocos em encostas naturais e taludes rochosos. Os métodos de análise de encostas buscam avaliar situações de risco e minimizar riscos, apoiados no conhecimento de propriedades dos maciços, como composição litológica, estruturas e caracteres das descontinuidades, graus de alteração e consistência das rochas. A aplicação prática consistiu na avaliação dos resultados de levantamento executado por meio de rapel em talude na cidade de Santos, SP, por empresa de consultoria. O levantamento identificou os principais sistemas de fraturas e delimitou blocos em situações instáveis para eventual remoção ou estabilização. Este estudo revela a grande importância das juntas de esfoliação, feições que podem promover, graças à progressiva desagregação intempérica, progressivo desplacamento e desprendimento de massas de rocha encosta abaixo.

PALAVRAS-CHAVE: Geologia Estrutural, queda de blocos, escorregamentos, estabilidade de encostas, Geologia, Ensino-aprendizagem. 


\section{Introdução}

Taludes ou encostas naturais podem ser definidos como superfícies inclinadas cujo substrato é de natureza terrosa, rochosa ou mista (solos e rochas), originados por diferentes processos geológicos e geomorfológicos. Podem apresentar modificações de origem antrópica como cortes, desmatamentos, introdução de cargas etc. O termo encosta é usualmente empregado em estudos de caráter regional, enquanto talude de corte é entendido como um talude modificado por escavações antrópicas de origens diversas. Talude artificial refere-se ao declive de aterros construídos a partir de materiais de diferentes granulometrias e origens, como rejeitos industriais, urbanos e de mineração. Escarpas são trechos de encosta caracterizados por altas declividades, em que predominam amplamente os fenômenos de queda de blocos.

Atualmente, investigações acerca da estabilidade de taludes e encostas podem ser relacionadas a três grandes áreas de aplicação: construção, manutenção e recuperação de grandes obras civis (rodovias, ferrovias, barragens etc.), explotação mineral, planejamento, mitigação e/ou consolidação de ocupações urbanas em áreas de encosta. $\mathrm{O}$ vasto campo de pesquisa interdisciplinar relacionado à avaliação da estabilidade de taludes, encostas naturais e escarpas - e à determinação dos parâmetros que permitam realizar diagnósticos de áreas instáveis e prever possíveis movimentos - tem evoluído cada vez mais com estudos científicos e tecnológicos que envolvem diferentes áreas, como Geologia, Geografia, Geomorfologia, Geologia de Engenharia, Mecânica dos Solos e das Rochas, e áreas de aplicação tecnológica, como Engenharia Civil e de Minas.

O movimento de encostas e taludes tem causado, nas ultimas décadas, muitos acidentes em diversas cidades brasileiras, na maioria das vezes com dezenas até, excepcionalmente, centenas de vitimas fatais. A análise e controle da instabilidade de taludes e encostas vêm se desenvolvendo com as grandes obras civis modernas, juntamente com novas técnicas de Engenharia e Geologia de Engenharia para prevenção e contenção, a finalidade desses trabalhos é a de que se evitem mais acidentes ou se minimizem seus efeitos. No Estado de São Paulo, Brollo e Ferreira (2009) assinalam que escorregamentos de encostas exigem a elaboração de planos preventivos de defesa civil e mapeamento de áreas de risco, porque constituem um dos prin- cipais tipos de fenômenos causadores de acidentes e desastres naturais.

O presente estudo sintetiza os resultados e conclusões de Trabalho de Conclusão de curso de Geologia produzido pelo primeiro autor (AMP), sob orientação do segundo (CDRC), na Unicamp (Pinotti 2011, Carneiro e Pinotti 2011, 2012). Descrevem-se as técnicas usuais de Geologia Estrutural para investigação do meio físico de áreas compostas por rochas fraturadas, importantes para compreensão do fenômeno da queda de blocos em escarpas, encostas naturais e taludes de corte. A previsão dos movimentos não é simples:

Dentre os movimentos de massa, a queda/rolamento de blocos é o tipo que possui maior dificuldade na previsão do início do processo, da trajetória e do alcance dos blocos (Ribeiro et al. 2009a, 2009b).

Para abordar de modo abrangente o conjunto de técnicas, é necessário caracterizar brevemente o fenômeno dos escorregamentos e analisar as condicionantes básicas do fenômeno da queda de blocos. A abordagem leva em conta o problema da regionalização de dados de fraturamento de maciços rochosos a partir de observações feitas no campo em pontos isolados, técnica que vem se aprimorando, diante do desafio de recompor a geometria interna dos maciços rochosos. Os resultados pretendidos são de utilidade prática não só para alunos de cursos de geologia interessados na área, mas também para geológos que procuram avaliar a qualidade e eficiência dos métodos que utilizam, e para profissionais de engenharia que trabalham na área e têm interesse em aprofundar-se nos estudos de geologia.

\section{Objetivos e métodos}

O objetivo geral deste projeto é elaborar uma síntese dos métodos e técnicas de Geologia Estrutural utilizados no estudo de encostas para prevenção e contenção de queda de blocos. Uma segunda finalidade é aplicar o conhecimento das técnicas para avaliar trabalho prático específico de Geologia Estrutural, que indicou medidas para minimizar o risco de escorregamentos e queda de blocos na área limítrofe dos municípios de Santos e São Vicente, na Baixada Santista, SP.

\section{Objetivos específicos}

Um objetivo específico do projeto é sintetizar conhecimentos e métodos analíticos para avaliação 
e análise de risco geológico envolvido em queda de blocos em encostas, sob a perspectiva das técnicas usuais de Geologia Estrutural. Os tópicos relacionados a esse tema incluem: (a) os fatores que controlam estabilidade de massas de regolito em encostas, com destaque para o problema da origem e movimentação de blocos de rocha, (b) as propriedades dos maciços rochosos que devem ser levadas em consideração nos estudos de encostas e levantamentos especificamente voltados para definir graus de estabilidade de massas rochosas, (c) os procedimentos, limitações e premissas da análise regional de fraturamento em maciços rochosos, técnica que busca determinar com a maior precisão possível a distribuição, padrões e feições diagnósticas dos sistemas de juntas e falhas que cortam uma dada região. Finalmente, a análise de risco geológico requer: (d) a revisão das técnicas de análise de estabilidade de encostas. Esse é o roteiro geral da primeira parte do trabalho.

Outro objetivo específico da pesquisa, que compóe a segunda parte do trabalho, é avaliar resultados, obtidos no campo do risco geológico, na execução de levantamentos de dados estruturais com técnicas de escalada em rapel e imageamento a laser, em encosta particularmente problemática do Granito Santos, na região urbana do município de Santos (SP).

A pesquisa foi essencialmente conduzida com base na literatura e em recentes dados estruturais coletados em campo por Bureau (2010).

\section{Método de trabalho}

Para atender aos objetivos da pesquisa, é preciso recuperar da literatura os fundamentos e técnicas analíticas de Geologia Estrutural, bem como os métodos utilizados em campo para avaliação de risco de queda de blocos. Pesquisa bibliográfica em livros e compêndios muito utilizados nesse campo do conhecimento foi o ponto de partida dos trabalhos. A recuperação de informações sobre as técnicas envolveu o levantamento de fontes, cruzamento de referências obtidas da literatura e estudo de numerosos artigos técnico-científicos em periódicos. Um número restrito de relatórios técnicos foi igualmente consultado, com a finalidade de dar aderência do projeto a situações e casos reais.

\subsection{Caracterização do objeto de estudo}

O objeto de estudo - a dinâmica de blocos rochosos em encostas - constitui um sistema, no sentido estrito proposto por autores como Christofoletti (1999). Com efeito, grande parte dos processos geomorfológicos "opera em sistemas claramente definidos que podem ser isolados para efeito de análise" (Strahler 1952). A primeira etapa da análise morfológica de sistemas é a definição do sistema a ser investigado (Christofoletti 1999), nesta etapa é preciso identificar o sistema e estabelecer seus limites, afim de que seja possível investigar sua estrutura e seu comportamento.

"As fronteiras do sistema devem distinguir entre os seus elementos componentes e os elementos de outros sistemas, levando-se em conta as características morfológicas como o contexto do aninhamento hierárquico nas grandezas espaciais. Essa tarefa exige o uso de conceitos operacionais (...)" (Christofoletti 1999).

O registro histórico das ocorrências integra o conjunto de medidas essenciais para avaliação do potencial de risco de uma dada região (Amaral 2009). Apesar desse fato, o presente estudo focaliza especificamente a dinâmica natural ligada ao fenômeno da queda de blocos e desplacamento, sem abordar os fatores relativos à ação antrópica, que pode se somar aos condicionantes geológico-geomorfológico-estruturais e determinar incidência de movimentos de massa catastróficos em encostas.

\subsection{Métodos de estudo estatístico de maciços rochosos}

O estudo das estruturas disruptivas presentes em corpos rochosos é essencialmente baseado no tratamento estatístico de dados estruturais. Diagramas de contorno, elaborados com base em populações representativas, quer de planos, quer de linhas, são indispensáveis para tratar dados em redes estereográficas do tipo igual-área. Tais operações não podem ser feitas em redes como Wulff, que preserva somente relações angulares. Apenas redes que conservam equivalência de áreas, como o diagrama de Schmidt-Lambert, permitem "estudo estatístico das estruturas medidas" (Carneiro et al. 1996).

O termo genérico fratura é aqui entendido como o conjunto formado pelas juntas, falhas, diáclases e juntas de esfoliação, essas feições recebem a denominação descontinuidades, em geotecnia. Em escala mesoscópica, é possível conhecer diretamente a orientação tridimensional de juntas 
e falhas a partir da medida direta da atitude de estruturas planares e lineares de feições isoladas. Especialmente as juntas, mas também as falhas, distribuem-se nos maciços rochosos na condição de sistemas ou famílias que compartilham a mesma orientação espacial, espaçamento regular e, muitas vezes, características estruturais similares. Para estabelecer as orientações das populações dominantes em um maciço rochoso é preciso recorrer a técnicas estatísticas. Procura-se determinar, mediante emprego das redes de contagem, concentrações preferenciais de fraturas. O quadro geral, de escala macroscópica, é obtido por meio da correlação e integração de dados de diversos afloramentos e exposições. Tal abordagem permite ao geólogo estabelecer a distribuição geométrica geral do fraturamento no corpo.

Os fundamentos teóricos desse campo de estudos sobre os corpos geológicos remontam aos trabalhos pioneiros de Bruno Sander sobre trama de rochas deformadas (Sander 1930, apud Turner e Weiss 1963, p. v). Por corpo geológico entende-se qualquer volume de rocha selecionado para estudo ou comentário, sem restrições quanto a tamanho (Turner e Weiss 1963, p. 15). Os estudos de Sander introduziram novos métodos geométricos para o que tem evoluído sob a designação análise estrutural. Qualquer corpo geológico, independentemente do tamanho, pode ser classificado como unidade isótropa ou anisótropa "cujos elementos estruturais internos comumente possuem configuração regular no espaço" (Turner e Weiss 1963, p. 6), são estudos que assumem um "sentido puramente qualitativo", pois:

Ao aplicar procedimentos geométricos, um geólogo deve estar sempre alerta de que não está fazendo análises estatísticas rigorosas. Em lugar disso, constrói imagens geométricas da configuração interna de domínios específicos dentro de um corpo geológico e, a partir destes, por extrapolação, esboça conclusões gerais sobre a estrutura do corpo rochoso como um todo. Não obstante, as técnicas envolvidas são de natureza estatística, porque, a partir das porções amostradas da população, são feitas generalizações sobre as propriedades da população como um todo. (Turner e Weiss 1963, p. 153).

\subsection{Avaliação de situações de risco em encostas}

A distinção entre situação de risco e acidente/ desastre natural é essencial para se avaliar a possível aplicabilidade da pesquisa. O tema assume interesse cada vez maior, principalmente para as populações potencialmente ameaçadas, mas também para os gestores públicos e instituições privadas, todos eles pressionados pelo crescimento populacional e pela contínua expansão das cidades, que consomem espaços naturais, à medida que os transformam, velozmente, em espaços urbanos.

Situações de risco são aquelas em que existe uma condição hipotética de danos a pessoas ou seus bens e serviços, provocada ou ameaçada por um suposto processo natural (Llorente e Laín 2009). Por desastre ou catástrofe natural entende-se a materialização de algum dano significativo derivado da ocorrência de determinado processo natural, em um dado local.

O estudo concentra-se na avaliação de risco de queda de blocos, ou seja, no estabelecimento de critérios geológico-estruturais para ocupação, preservação ou até mesmo proteção permanente de áreas potencialmente instáveis. Como modo de aplicar os conceitos, analisou-se a sistemática utilizada em levantamentos de encosta onde pode ocorrer queda de blocos, tendo como exemplo o Granito Santos.

Os resultados obtidos possibilitam discutir as metodologias atualmente empregadas, buscando classificá-las como eficientes ou não. Finalmente, procurou-se avançar na definição de um método de trabalho para tais investigações, apoiado nos fatores inerentes a um projeto de encostas, tais como condicionantes geológicos, parâmetros considerados e estratégia a ser adotada.

\section{Interesse prático da pesquisa}

Os estudos geológicos e estruturais na região do Morro de Santa Terezinha merecem destaque devido a diversos episódios de acidentes geológicos que provocaram perda de vidas humanas e perdas materiais.

Em 1 de março de 1956, durante um episódio de chuva intensa que durou cerca de quatros horas, com precipitação de $120 \mathrm{~mm}$, uma série de escorregamentos ocorreu no Morro Santa Terezinha, perto da pedreira então em atividade. O escorregamento causou grande destruição, resultando na morte de 21 pessoas, mais de quarenta feridos e a destruição de cerca de cinquenta casas, sendo classificado como um escorregamento de rocha (rock slide). Na noite de 24 de março de 1956, estendendo-se à madrugada do dia seguinte, houve novo caso de chuva intensa, 
registrando-se precipitação de $250 \mathrm{~mm}$ em período de 10 horas, que ocasionou nova série de escorregamentos em quase todas as encostas dos morros de Santos e cidades vizinhas. Nessa ocasião 43 pessoas foram mortas, houve muitos feridos e mais de 100 casas foram total ou parcialmente destruídas. Nessa noite, ocorreu um escorregamento no Morro do Marapé, que foi um dos mais catastróficos e merece menção especial devido ao aspecto peculiar da ocorrência e respectiva formação. Localizado na pedreira do Morro de Santa Terezinha, a norte do "rock slide" ocorrido 24 dias antes, o escorregamento reincidiu em local onde por erosão havia se formado uma ravina, local de escoamento de uma pequena corrente de água. Prossegue o autor:

"A meia altura da encosta deste morro e vindo da parte norte do morro do Embaré, um pequeno escorregamento, envolvendo cerca de $1.500 \mathrm{~m}^{3}$ de detritos, ocorreu e desbloqueou o talvegue. A bacia atrás dessa barragem encheu-se rapidamente com água da chuva que caía com grande intensidade. Quando essa barragem cedeu devido às águas que se acumulavam, todo o material que havia no local e mais a água acumulada, desceu pelo talvegue, arrastando em seu caminho ainda, o material erodido na ravina (Pichler 1957).

Outros acidentes ocorridos em 1978-1979 na área de estudo foram citados por Prandini et al. (1980). Diante do notável histórico de acidentes, novos estudos geológicos e estruturais na região do Morro de Santa Terezinha são importantes para evitar, ou ao menos mitigar, novos casos. Esse é o objetivo perseguido no projeto de instalação de um parque de laser no sopé da encosta (Bureau 2010), atualmente em fase de edificação.

\section{Estabilidade de massas de regolito em encostas}

Nas condições do ambiente superficial, sobretudo em regiões tropicais e subtropicais úmidas, em que historicamente predominam condições de altas temperaturas médias anuais e intensa precipitação na forma de chuvas, os processos de denudação atuantes sobre maciços rochosos promovem aparecimento de espessas coberturas inconsolidadas. Sob tais condições de clima, a movimentação lenta ou rápida da cobertura é inerente à dinâmica natural. A resposta das formas de relevo às ações antrópicas ou naturais, capazes de promover instabilidade, pode ser mais catastrófica ou de menor impacto a depender dos padrões de "uso e manejo do solo, e também das características do meio físico" (Carvalho e Corrêa 2009).

O regolito constitui o manto de decomposição que recobre a superfície da Terra, situado acima do substrato rochoso, é formado por massas de rochas, solos e, dependendo da história geológica local, material coluvionar e sedimentos recentes. Reunidos sob a designação de escorregamentos ou movimentos de massa, os processos muitas vezes apresentam transições graduais entre si, o que dificulta a classificação. As massas que integram o regolito constituem mistura pouco coesa de partículas de solos e rochas e passível de se deslocar em virtude da ação da gravidade. Embora inexista participação direta de agentes de transporte como a água, gelo ou vento, sabe-se que a água exerce papel fundamental no processo (Nelson 2003).

Este estudo focaliza especificamente o fenômeno de movimentação de blocos e placas de rocha, cuja origem está ligada a um tipo de resposta do maciço rochoso às condições superficiais, ao longo do tempo. O desplacamento e rolamento de blocos podem associar-se ao desabamento de grandes massas, devido à ação da gravidade.

Para compreender os processos que determinam a tendência de se desenvolver, em alguns tipos de maciços rochosos, extensas placas ou matacões chatos formados por rocha pouco decomposta, é necessário levar em conta o fenômeno da esfoliação, predominante em áreas sustentadas por rochas ígneas.

Rochas ígneas massivas que possuem pouca ou nenhuma estrutura parecem ser particularmente suscetíveis à esfoliação. Os granitos exibem o grau mais acentuado de esfoliação, ao passo que rochas ígneas de baixo conteúdo de sílica tais como gabro, piroxenito e peridotito geralmente mostram estruturas de esfoliação menos proeminentes que aquelas de alto conteúdo em sílica (Legrand 1949).

Algumas rochas ígneas desenvolvem extensos planos subparalelos de partição, denominados esfoliação, que são aproximadamente paralelos à superfície do terreno. Os planos de esfoliação são mais ou menos obscuros em rochas metamórficas; embora possam estar presentes, eles podem ser obliterados ou mascarados por outros planos estruturais existentes na rocha. Assim, em rochas metamórficas de baixo mergulho, planos de esfoliação podem 
coincidir com planos de partição estrutural.

Uma movimentação de blocos de rocha ocorre quando um pedaço de rocha desloca-se sobre uma encosta íngreme e cai até a base, enquanto a queda de detritos envolve uma mistura de solo, regolito e rochas. $\mathrm{O}$ material depositado acumula-se na base da encosta, na forma de tálus.

$\mathrm{Na}$ Figura 1 pode-se ver que quanto maior a inclinação do talude, será maior o valor de $\mathrm{g}_{\mathrm{t}}$ (componente tangencial da gravidade responsável pelo movimento), enquanto o valor de $g_{p}$ (componente perpendicular da gravidade que mantém o bloco parado no talude) será cada vez menor.

A interferência humana pode também ocasionar, ou ao menos acelerar fenômenos de movimentação de blocos de rocha. Define-se tal movimentação como uma ação de queda livre (Copons e Tallada 2009), a partir de uma elevação, com ausência de superfície de movimento, exceto em casos de desplacamento. As causas da movimentação de blocos podem estar associadas à variação térmica do maciço rochoso, perda da sustentação dos blocos por ação erosiva da água, alívio de tensões, vibrações e outras (Guidicini e Nieble 1984). Embora as quedas de blocos não sejam comparáveis, em relação a impactos econômicos e prejuízos causados, aos efeitos de outros tipos de movimentos de massa de grandes proporções em encostas de zonas montanhosas, estima-se que o número de mortes causados por esse tipo de desastre em rodovias e ferrovias seja equivalente aos provocados pelas demais formas de instabilidade de encostas (Hoek 2007).

Os processos de movimentação de blocos de rocha em encostas consistem em deslocamentos por gravidade, cuja velocidade pode ser extremamente rápida (Knapp et al. 1991). Uma classificação bastante utilizada dos processos é proposta por Infanti Jr. e Fornasari Fo (1998):
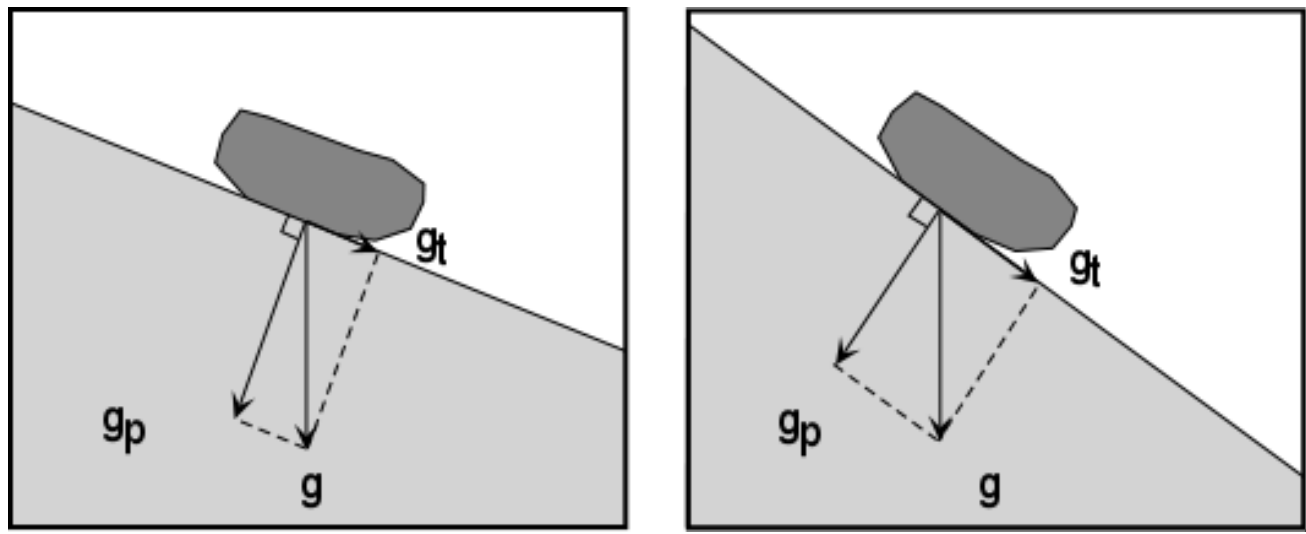

Figura 1. Esquema mostrando a tendência de um bloco de rocha se movimentar devido à inclinação do talude e às componentes da gravidade (Fonte: http://www.tulane.edu/ sanelson/geol111/masswasting.htm) 


\subsection{Fatores predisponentes}

A Geologia Estrutural deve ser considerada parte fundamental no estudo de casos isolados e em abordagens regionais sobre o potencial de ocorrência de escorregamentos numa determinada área. Como fator predisponente destes processos, as estruturas exercem enorme influência sobre outras condionantes controladores de sua deflagração (perfil de solo, forma das encostas, fluxo d'água subterrânea e superficial, escavabilidade dos materiais superficiais). (Porto et al. 2005).

Fatores predisponentes (Guidicini e Nieble 1976) constituem um conjunto de condições geológicas, geométricas e ambientais sob as quais acontecem movimentos de massa. As características intrínsecas do maciço representam somente condições naturais, sem participação, em nenhum momento, da ação antrópica. Pode-se distinguir os seguintes fatores:

- complexo geológico: natureza petrográfica, estado de alteração por intemperismo, acidentes tectônicos (falhamentos, dobramentos), atitude das camadas (orientação e mergulho), formas estratigráficas, intensidade de diaclasamento etc;

- complexo morfológico: inclinação superficial, massa, forma de relevo;

- complexo climático-hidrológico: clima, regime de águas meteóricas e subterrâneas;

- gravidade;

- calor solar;

- tipo de vegetação original.

Os fatores específicos para determinar queda de blocos são: tipos de rochas e grau de alteração das unidades litológicas, foliação das rochas (se estiver presente ou não) e descontinuidades (tais como sistemas de juntas, falhas e fraturas de alívio).

Um padrão mais restrito a maciços graníticos, diretamente ligado a mecanismos de queda de blocos, é o das fraturas sub-horizontais que acompanham a forma geral das encostas. O papel exercido por esse tipo de juntas é fundamental, porque elas favorecem o processo. As fraturas recebem a designação de juntas de desplacamento ou de esfoliação, porque constituem um modo de controle da esfoliação do corpo rochoso, como no caso do Parque Yosemite, EUA. Fraturas sub-horizontais permitem percolação de água e aparecimento de subpressões, além de favorecer a aceleração de fenômenos de intemperismo químico ao longo das superfícies, o desenvolvimento de raízes e a diminuição do grau de fixação das massas rochosas por elas limitadas.

\subsection{Fatores efetivos}

Fatores efetivos são aqueles que agem diretamente na dinâmica que desencadeia a queda de blocos, agindo sob inúmeras combinações possíveis, incluindo a ação humana, em função da participação de cada agente. A atuação dos agentes efetivos se divide em duas categorias: os agentes efetivos preparatórios e efetivos imediatos.

\subsubsection{Fatores efetivos preparatórios}

Os fatores efetivos preparatórios podem ser climáticos ou antrópicos. Os fatores efetivos preparatórios climáticos abrangem a variação da temperatura, a erosão pela água (ou vento), a pluviosidade anterior a um determinado episódio de chuva etc. No caso de maciços rochosos, a erosão pode causar mudanças de geometria externa, além de promover acumulações detríticas por vezes em situações instáveis, que são os chamados corpos de tálus. Pontos de surgência de água subterrânea podem contribuir para instabilização do maciço, retirando material incoerente. Os fatores efetivos preparatórios antrópicos podem ser classificados em três conjuntos: desmatamento, alterações na rede de drenagem e uso inadequado da área.

\subsubsection{Fatores efetivos imediatos}

Os fatores efetivos imediatos são aqueles que deflagram, ou seja, provocam diretamente a movimentação de blocos de rocha, atuando nos momentos finais do processo de instabilização do maciço, seja durante intervalos de tempo da ordem de segundos, alguns minutos ou poucas horas. $\mathrm{O}$ agente de maior importância é a chuva intensa, mas vibrações provenientes de sismos, terremotos, cortes para obras civis ou do desmonte de pedreiras com explosivos podem ser agentes deflagradores de queda de blocos em maciços cujas condições de estabilidade sejam criticas.

As causas de movimentos de massa podem ser separadas em função da sua posição em relação ao talude ou encosta considerada (Terzaghi 1967), sendo distinguidos três categorias:

- causas internas: levam ao colapso sem que se verifique qualquer mudança nas condições geométricas do talude e que resultam de uma diminuição da resistência interna do material (aumento da pressão hidrostática, 
diminuição da coesão e ângulo de atrito interno por processo de alteração);

- causas externas: provocam o aumento das tensões de cisalhamento, sem que haja diminuição da resistência do material (aumento do declive do talude por processos naturais ou artificiais, deposição de material na porção superior do talude, abalos sísmicos e vibrações);

- causas intermediárias: resultam de efeitos causados por agentes externos no interior do talude (liquefação espontânea, rebaixamento rápido, erosão retrogressiva).

\section{Propriedades dos maciços rochosos}

A estabilidade e a deformação de maciços rochosos dependem, na maioria das vezes, da presença de descontinuidades. Segundo Serra e Ojima (1998), um maciço rochoso fraturado é geralmente mais heterogêneo e anisotrópico do que outro que apresente menor quantidade de descontinuidades ou planos de fraqueza. As descontinuidades comuns, que ocorrem nos maciços rochosos, são representadas por juntas, falhas, contatos litológicos e foliações metamórficas. Assim, um maciço rochoso natural é um agregado de blocos descontínuos, de formas geométricas irregulares, muitas vezes alternados com zonas de rochas intemperizadas e portadoras de distintas propriedades físicas.

Para realizar análise das descontinuidades de um maciço rochoso deve-se descrever suas feições estruturais por meio de medidas de orientação, apresentadas em diagramas e mapas. Apesar de importantes, esses dados são insuficientes por si só para definir de maneira clara e objetiva o arranjo dos sistemas de fraturas de corpos rochosos e sua geometria. Com esse objetivo em mente, o modelo estrutural deve apresentar os tipos de estruturas e idades relativas, por meio de estudos da geometria e cinemática dos maciços (Magalhães e Cella 1998).

A presença de descontinuidades no maciço, bem como a alteração das rochas por processos intempéricos são os principais fatores no controle de sua resistência mecânica e deformacional. A avaliação das propriedades geotécnicas de um maciço rochoso inclui o conhecimento da composição litológica, seu estado de alteração, sua coerência (tenacidade) e determinação em campo da ocorrência e características das descontinuidades no maciço.

\section{Composição litológica}

A composição litológica se refere ao tipo de rocha presente no maciço, sendo classificada por meio de conceitos da Petrografia. A classificação litológica, ou petrográfica, quando aplicada em Geologia de Engenharia, deve se valer dos conceitos básicos da Geologia, mas ao mesmo tempo deve ser simples e objetiva, sem a necessidade de nomenclaturas complexas, que dificultam os trabalhos práticos.

Para facilitar a classificação, a Comissão de Mapeamento de Geologia de Engenharia da International Association for Engineering Geology and Environment (IAEG 1981) apresentou classificação baseada em um número limitado de "rochas tipo". A classificação litológica nem sempre discrimina a variação real de uma rocha em determinado local, valendo-se assim da determinação adicional de variedades de um mesmo litotipo.

A identificação litológica é importante devido às relações entre conteúdo rochoso e as características do maciço, que condicionam o comportamento quanto ao seu uso em engenharia. Além disso, os dados permitem avaliar os campos de variação das propriedades físicas e mecânicas da rocha, porque determinado tipo de rocha poderá apresentar parâmetros mecânicos dentro de determinado campo de valores, diferentes de outro tipo litológico. A caracterização litológica permite ainda avaliar a possibilidade de se extrapolar resultados de ensaios pontuais para o maciço como um todo.

\section{Alteração}

Os principais tipos de alteração que podem afetar as rochas são a alteração primária, que ocorre em ambientes endógenos, sobretudo dependente de fenômenos magmáticos, e a alteração intempérica, que se dá em função da ação de agentes predominantes nos ambientes exógenos, sob as diferentes condições de interação do conjunto atmosfera-hidrosfera-biosfera-geosfera. Apesar de algumas rochas apresentarem o primeiro tipo de alteração, em Geologia de Engenharia o segundo tipo de alteração é considerado o mais importante. Essa importância é atribuída ao fato de os processos intempéricos provocarem diminuição da resistência mecânica, aumento da deformabilidade e modificação da permoporosidade das rochas. A alteração, frequentemente, também é chamada de decomposição, termo que incorpora o conceito de perda das propriedades geomecânicas dos maciços rochosos. 
Em regiões de clima tropical, como é o caso do Brasil, a ação intempérica é predominantemente químico-biológica, podendo afetar os maciços rochosos até grandes profundidades. O comportamento de diferentes rochas sob condições intempéricas pode fazer com que os maciços possuam maior ou menor anisotropia, condicionada pela existência de camadas, níveis, bandas ou setores mais suscetíveis à alteração.

A caracterização do estado de alteração da rocha é feita por meio tátil e visual, baseando-se nas variações de brilho, cor dos minerais, cor da rocha, da tenacidade e friabilidade. A Tabela 1 apresenta um exemplo de siglas e denominações mais utilizadas (IPT 1984) na avaliação do estado de alteração das rochas, e critérios adotados para definição dos graus da intensidade dessa alteração.

\section{Coerência}

Coerência é definida com base nas propriedades de tenacidade, coesão, dureza e friabilidade das rochas. É caracterizada de forma tátil e visual por intermédio da análise da resistência que a rocha apresenta ao impacto do martelo e ao risco com lâmina de aço (Guidicini et al. 1972).

As denominações e siglas bem como os critérios usados para definir a coerência das rochas constam na Tabela 2. Assim como a alteração, a coerência é um critério relativo utilizado para comparação entre as variações de um mesmo litotipo.

Os parâmetros de coerência e alteração, apesar de serem subjetivos, permitem medir de forma prática e confiável a intensidade do intemperismo sobre um determinado maciço rochoso, importante para a Geologia de Engenharia. Em termos gerais, os estágios iniciais de alteração resultam em significativa diminuição da resistência mecânica (e portanto, da coerência) da rocha, em relação à rocha original, enquanto em estágios mais avançados de alteração a variação da resistência não será tão perceptível.

\section{Tipos de descontinuidades}

Os maciços rochosos apresentam diferentes tipos de descontinuidades, que exercem grande influência na estabilidade de taludes. Recebem a denominação genérica de fraturas, muitas vezes organizadas segundo orientações preferenciais bem definidas, sendo divididas em diáclases, juntas e falhas. Diáclases constituem um tipo de estrutura primária de rochas ígneas, formadas em estágios tardios ou finais da cristalização/consolidação de magmas, quando esforços causados por contração do corpo de rocha controlam o aparecimento de descontinuidades. Falhas e juntas são descontinuidades classificadas como estruturas secundárias, diferem entre si em função da existência de deslocamentos relativos dos blocos separados pelos planos. Juntas são fraturas de origem geológica ao longo das quais não ocorreu qualquer deslocamento perceptível (Ramsay e Huber 1987). A influência das descontinuidades depende das orientações em relação ao talude e do seu arranjo no maciço, da resistência ao movimento ao longo da superfície, da persistência, do espaçamento, da presença de material decomposto ao longo dos planos ou existência de eventual preenchimento das fraturas, bem como da facilidade com que a água pode percolar ou se acumular ao longo das mesmas.

Tabela 1. Graus de alteração de rochas (IPT 1984)

\begin{tabular}{|c|c|c|}
\hline Siglas & Denominações & Características da rocha \\
\hline A1 W1 RS & Rocha sã ou praticamente sã & $\begin{array}{l}\text { Apresenta minerais primários sem vestígios de altera- } \\
\text { ção ou com alterações físicas e químicas incipientes. } \\
\text { Neste caso, a rocha é ligeiramente descolorida. }\end{array}$ \\
\hline A2 W2 RAD & Rocha medianamente alterada & $\begin{array}{l}\text { Apresenta minerais medianamente alterados e a rocha } \\
\text { é bastante descolorida. }\end{array}$ \\
\hline A3 W3 RAM & Rocha muito alterada & $\begin{array}{l}\text { Apresenta minerais muito alterados, por vezes pulve- } \\
\text { rulentos e friáveis. }\end{array}$ \\
\hline A4 W4 REA & Rocha extremamente alterada & $\begin{array}{l}\text { Apresenta minerais totalmente alterados e a rocha é } \\
\text { intensamente descolorida, gradando para cores de solo. }\end{array}$ \\
\hline
\end{tabular}


Tabela 2. Graus de coerência (Guidicini et al. 1972)

\begin{tabular}{l|l|l}
\hline \multicolumn{1}{l}{ Siglas } & Denominaçóes & \multicolumn{1}{c}{ Características da rocha } \\
\hline C1 & Rocha coerente & $\begin{array}{l}\text { Quebra com dificuldade ao golpe do martelo, produzindo } \\
\text { fragmentos de bordas cortantes. Superfície dificilmente } \\
\text { riscável por lâmina de aço. Somente escavável a fogo. }\end{array}$ \\
\hline C2 & Rocha medianamente coerente & $\begin{array}{l}\text { Quebra com dificuldade ao golpe do martelo. Superfície } \\
\text { riscável com lâmina de aço. Escavável a fogo. }\end{array}$ \\
\hline C3 & Rocha pouco coerente & $\begin{array}{l}\text { Quebra com facilidade ao golpe do martelo, produzindo } \\
\text { fragmentos que podem ser partidos manualmente. Super- } \\
\text { fície facilmente riscável com lâmina de aço. }\end{array}$ \\
\hline Rocha incoerente & $\begin{array}{l}\text { Quebra com a pressão dos dedos, desagregando-se. Pode } \\
\text { ser cortada com lâmina de aço. Friável e escavavel com } \\
\text { lâmina. }\end{array}$ \\
\hline
\end{tabular}

Embora sejam descontinuidades tanto as juntas, como as falhas, diáclases ou as zonas de cisalhamento rúptil, os termos fratura e junta são, muitas vezes, empregados de forma genérica. Para Hasui e Mioto (1992), juntas (ou diáclases) são planos de ruptura das rochas com características físicas e mecânicas similares, que ocorrem em arranjo paralelo ou subparalelo, compondo famílias. Frequentemente, as juntas podem se agrupar em duas ou mais famílias, constituindo um sistema. As famílias podem apresentar características diferentes uma das outras devido à sua origem mecânica ou situação na história geológica da área.

Descontinuidades ao longo das quais houve movimentação relativa de blocos são as falhas, paráclases ou zonas de cisalhamento, rúptil ou dúctil. Em muitos casos, o atrito de um bloco contra o outro impõe fragmentação às rochas. A espessura de fragmentação das rochas pode se limitar a uma pequena extensão ou pode alcançar centenas de metros, neste caso sendo denominada zona de falha. As falhas e zonas de falha podem ser definidas por um ou mais planos, estrias de atrito (slikensides) e por produtos da fragmentação e cominuição de rochas, que constituem as séries de rochas cataclásticas ou, quando as deformações se dão sob condições dúcteis, as séries de rochas miloníticas.

\subsection{Planos de acamamento}

Rochas sedimentares apresentam planos de acamamento, ou estratificação reliquiar, formados a partir da deposição de sedimentos em camadas, que são diferentes planos de separação e que muitas vezes apresentam propriedades físicas distintas entre si. A exceção são algumas feições sedimentares como a estratificação cruzada ou estruturas internas de deformação atectônica, como deslizamento subaquoso ou até mesmo escorregamentos pós-deposicionais. Nas rochas metamórficas paraderivadas é comum a preservação de planos de estratificação reliquiar, que se apresentam em geral subparalelos e concordantes entre si, apresentam grande persistência lateral e estendem-se por grandes áreas. As características e a inclinação das camadas, mesmo quando se trata de pacotes metassedimentares, são importantes no estudo de estabilidade de maciços rochosos.

\subsection{Planos de juntas}

Planos de juntas são encontrados em praticamente todos os tipos de rocha. São estruturas planares formadas pela atuação ou relaxamento de tensões, ao longo das quais quase não há movimentação. Comumente ocorrem em famílias e são de grande importância na estabilidade de taludes. Superfícies lisas, contínuas e com orientação favorável podem constituir perigosos planos de movimentação para obras de engenharia, assim como podem influenciar grandemente as vertentes naturais, taludes de estradas etc. Famílias de juntas podem ser paralelas ou subparalelas a falhamentos, uma vez que ambos os tipos de estruturas apresentam relações genéticas. 


\subsubsection{Juntas de Esfoliação}

Juntas de esfoliação ou juntas de alívio de carga são descontinuidades extensas, não necessariamente limitadas a superfícies planas (Bahat et al. 1999), pois em muitos casos formam surperfícies curvas, subparalelas à superfície do terreno, promovem separação de placas de rocha, em geral subparalelas umas às outras (Fig. 2). Sua origem "permanece mal-esclarecida, a despeito do fato de as feições serem conhecidas há mais de dois séculos" (Martel 2006), a maior parte da literatura sobre juntas concentra-se em seu significado tectônico, e quando menciona as juntas de esfoliação o faz com o intuito de deixá-las fora de consideração (Harland 1957). As juntas de esfoliação normalmente concentram-se próximo à superfície, tornando-se mais espaçadas com a profundidade, podendo desaparecer a algumas dezenas de metros de profundidade. O processo resulta na subdivisão da rocha em placas, um fator especialmente importante no controle da ocorrência de água subterrânea em áreas graníticas (Legrand 1949).

Bradley (1962) propõe classificá-las com base na origem: (a) a esfoliação termal resulta do aquecimento da rocha a altas temperaturas, (b) a esfoliação química ocorre quando mudanças na composição química global da rocha induzem aumento de volume, (c) a esfoliação física, ou "sheeting", é comumente observada na forma de superfícies convexas em rochas cristalinas massivas, que são aqui denominadas simplesmente juntas de esfoliação. São causadas pela liberação de carga, quando a erosão expõe rochas que estiveram enterradas em grandes profundidades. Juntas de esfoliação são mais bem desenvolvidas em áreas onde ocorreu diminuição de pressão confinante sob elevada taxa de compressão (P),paralela à superfície (Martel 2006). Desse modo, as juntas de esfoliação resultam da interação entre as tensões internas da Terra com a massa de rochas e a topografia.

Fraturas abertas por esfoliação formam superfícies subparalelas à superfície do terreno, delimitando lajes concêntricas de rocha que lembram as cascas de uma cebola, como pode ser visto no Par-

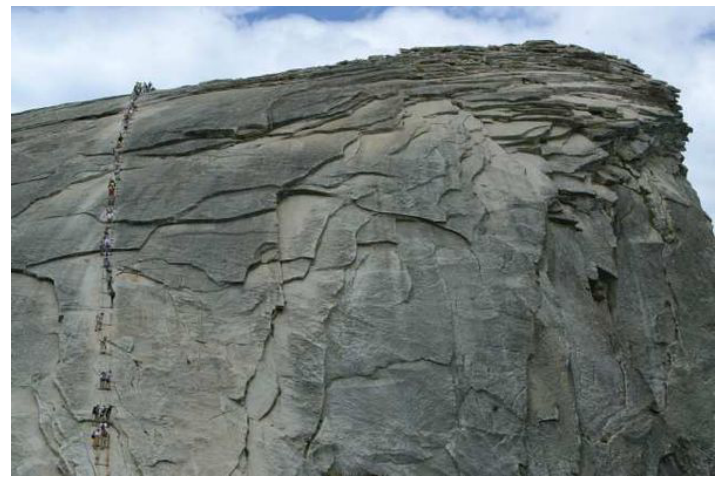

Figura 2. Juntas de esfoliação física no Yosemite National Park, EUA. As descontinuidades acompanham aproximadamente a superfície do terreno, lembrando uma casca de cebola (Fonte: Buckingham et al. s.d. URL: http://wilderness-exp1-fa10.wikispaces.com/ Group+One).

que Nacional de Yosemite, nos EUA (Fig. 2). Essas grandes fraturas acham-se presentes em formações rochosas de todo o mundo, possuem dimensões da ordem de centenas de metros e exercem grande influência sobre o fluxo de águas subterrâneas. Embora sejam formadas em resposta à "remoção de carga”, as fraturas não se abrem pelo simples alívio da tensão de compressão.

Fluidos de alta pressão, efeitos termais, heterogeneidade da rocha e intemperismo também são rejeitadas como as principais causas desses tipos de fraturas. Esforços de tração perpendiculares à superfície são necessários para que grandes fraturas de esfoliação se abram, o que tem sido explicado pela incidência de tensões compressivas paralelas à superfície do terreno. Técnicas numéricas e analíticas para corpos elásticos bidimensionais mostram que, em zonas sujeitas a forte tensão compressiva paralela à superfície, desenvolvem-se tensões localizadas de tração, perpendiculares à superfície do terreno (Fig. 3).

Reconhecer a presença de juntas de esfoliação é de extrema importância em Geologia de Engenharia, principalmente devido à sua influência na estabilidade de taludes. Juntas de esfoliação que seguem a topografia de paredes inclinadas de vales,

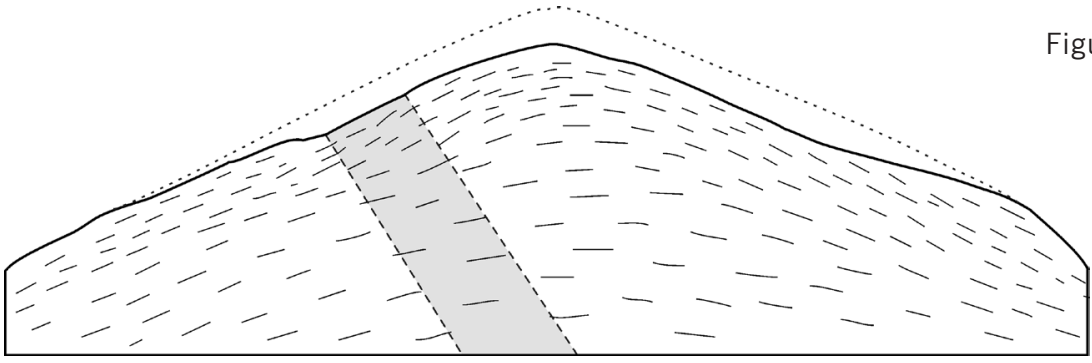

Figura 3. Esquema, em perfil, de juntas de esfoliação (Modif. de Jahns 1943, apud Martel 2006). A linha pontilhada indica a superfície topográfica na época em que se formaram as juntas, que afetam distintos tipos de rocha (regiões claras e escuras do desenho) 
encostas de morros rochosos e falésias podem criar blocos de rochas propensos a escorregamento. $\mathrm{O}$ deslizamento ao longo de planos de esfoliação é comum se o mergulho da junta exceder o ângulo de atrito da mesma, especialmente quando o sopé do talude estiver enfraquecido (naturalmente ou por ação antrópica).

\subsection{Planos de falha}

Falhas ocorrem em menor frequência do que juntas, e afetam todos os tipos de rocha. Os planos de falha caracterizam-se por separar blocos que sofreram deslocamentos, de pequeno porte ou até mesmo com distâncias consideráveis. A nomenclatura de falhas abrange termos que guardam um sentido histórico, formados desde a prática de antigos mineiros. A classificação mais usual baseia-se na determinação do movimento relativo de blocos, porém, para evitar ambiguidade, é comum o uso de classificação de natureza genética. Reconhecem-se assim as falhas de gravidade (ou "normais"), de empurrão (ou "inversas") e transcorrentes (ou "direcionais"). Falhamentos originam, na maioria das vezes, planos de fraqueza contínuos e persistentes. Muitas vezes as zonas de falha podem ser caracterizadas por uma série de superfícies de deslocamento, dispostas em faixa de material cominuído e frequentemente alterado, que compõe as rochas das séries miloníticas. Em certos casos, dobras de arrasto (ou seja, planos de acamamento dobrados e adjacentes às falhas) podem provocar deslizamentos ao longo dos planos de acamamento, uma vez que essas superfícies de fraqueza podem induzir ou desencadear o movimento em encostas.

\subsection{Foliação metamórfica}

A foliação metamórfica é restrita a rochas que sofreram algum tipo de metamorfismo. A estrutura caracteriza-se pela propriedade de dividir e separar a rocha em fatias ou lâminas, paralelas a subparalelas, sendo feição típica de xistos, filitos e gnaisses. Dependendo do grau metamórfico e dos sucessivos estágios de dobramento e redobramento aos quais a rocha foi submetida, podem ser encontradas variações desse tipo de estrutura. Dessa forma, a xistosidade, a clivagem ardosiana e a clivagem de crenulação representam planos de fácil separação, enquanto a estrutura gnáissica e o bandamento metamórfico não são considerados bons planos de partição, ainda mais quando a rocha ainda é pouco intemperizada.

Planos de foliação também podem ser desenvolvidos ao longo de grandes falhas ou zonas de cisalhamento. As descontinuidades resultantes podem ser lisas e contínuas, e normalmente representam os elementos tectônicos mais importantes em estudos de estabilidade.

\subsection{Discordâncias ou inconformidades}

No processo de sedimentação, as superfícies de discordância e as inconformidades representam hiatos de tempo. São quebras com significado estrutural, porque alguma erosão ou inclinação das camadas subjacentes ocorreu antes de outro material ser depositado sobre elas. Discordâncias normalmente se distribuem por grandes áreas e apresentam superfície irregular, com mudanças bruscas de inclinação. Superfícies de discordâncias marcam mudanças nas propriedades geotécnicas das rochas, principalmente se uma antiga superfície de alteração ficar preservada, com a presença de paleossolo, constituindo assim uma zona de fraqueza.

\subsection{Bordas de intrusões ígneas}

Bordas de intrusões ígneas podem cortar o acamamento quando intrudidas em sequências sedimentares, como por exemplo, em diques e batólitos, ou serem encontradas paralelamente ou subparalelamente ao acamamento, como no caso de sills ou soleiras. Geralmente, junto a essas margens, as rochas encaixantes são afetadas pelo calor e por consequência podem ter alteradas suas propriedades de resistência mecânica e propensão ao intemperismo. A percolação de água superficial ou de soluções hidrotermais pode levar à alteração das rochas, principalmente ao longo de planos de fraqueza, aumentando assim a instabilidade do maciço.

\subsection{Planos de cisalhamento e fendas de tração}

Planos de cisalhamento são resultados de movimentos, sejam recentes ou antigos, das rochas e podem afetar a estabilidade de taludes, especialmente se foram afetados ou sobrecarregados por cortes de estradas ou atividades de mineração. Fendas de tração são feições recentes nos maciços e podem ser encontradas, geralmente, nas partes superiores dos taludes, indicando precariedade na estabilidade do maciço. 


\section{Parâmetros de caracterização de descontinuidades}

As estruturas dos maciços que mais interessam à investigação aplicada a queda de blocos são as descontinuidades, cujas propriedades mais importantes são: orientação espacial, persistência ou continuidade da estrutura, espaçamento, rugosidade, abertura e preenchimento e por fim a possibilidade de haver percolação de água através das descontinuidades. A resistência de um maciço rochoso é dependente de um ou mais desses fatores.

Em sua maioria, as propriedades das descontinuidades apresentam origem geométrica e expressam-se com grande variação espacial, mesmo em um único maciço rochoso. Diversos tipos de estudos estatísticos de distribuição podem ser utilizados para descrever a variação das propriedades, uma vez que alguns tipos de comportamento repetem-se com significativa constância, como por exemplo, o espaçamento entre as descontinuidades. A seguir são descritos os principais parâmetros para caracterização de descontinuidades com enfoque na geologia e na geomecânica.

\subsection{Orientação espacial}

As descontinuidades presentes nos corpos rochosos, em particular juntas e falhas, distribuem-se espacialmente segundo orientações preferenciais, agrupando-se em juntas ou famílias. A orientação preferencial é uma consequência das tensões geológicas atuantes durante a época de formação das estruturas. Dependendo da história geológica da região, pode não haver qualquer relação entre a orientação original das tensões com as famílias de descontinuidades do maciço.

A orientação espacial de cada descontinuidade é expressa em termos de sua direção (definida pelo ângulo que a interseção do plano da descontinuidade, com o plano horizontal, faz com a direção norte) e pelo ângulo de mergulho (ângulo de inclinação do plano com o plano horizontal, sendo a reta do mergulho a reta de máxima inclinação no plano e perpendicular à direção), conforme apresentado na Figura 4.

\subsection{Persistência}

Persistência ou continuidade de uma fratura é o parâmetro ligado ao tamanho e à forma geométrica da estrutura. Tanto a forma, quanto as

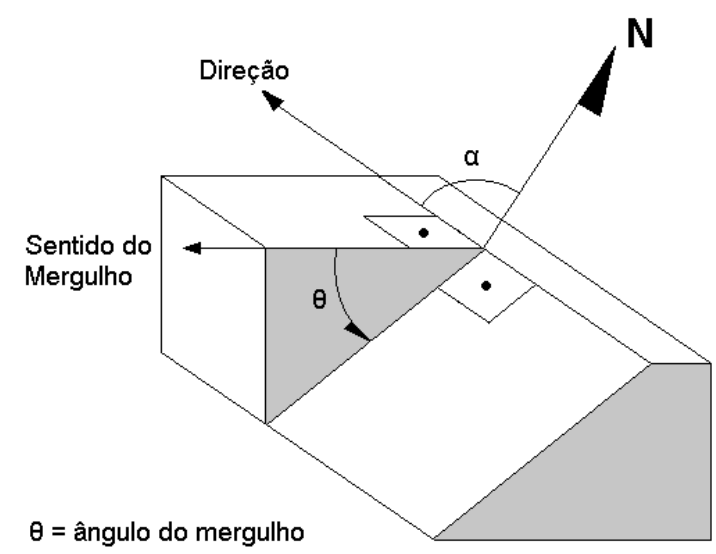

Figura 4. Definição de orientação espacial em estruturas geológicas planares (Modif. de MAGALHÃES e CELLA 1998)

dimensões de uma fratura podem ser controladas por características geométricas do maciço rochoso. A persistência pode ser classificada de acordo com a Tabela 3.

Segundo Magalhães e Cella (1998), a persistência de uma fratura é condicionada, também, pela sua ordem de aparecimento em uma sequência de eventos de fraturamento. Juntas recentes sempre têm a tendência de se originar a partir de uma superfície mais antiga ou de se interromper nelas, podendo depender do tipo de rocha, presença de falhas ou de outras juntas. Por outro lado, fraturas de cisalhamento conjugadas podem se interceptar mutuamente, sem predominar ou interromper localmente uma ou outra.

A alta ou baixa de persistência das juntas nos maciços rochosos determinam seu padrão de compartimentação. A persistência de dois sistemas de descontinuidades ortogonais entre si não é suficiente para a formação de um bloco rochoso, enquanto dois sistemas oblíquos entre si apresentam maior probabilidade de formar blocos. Em geral, são necessárias pelo menos três famílias sistemáticas de juntas, razoavelmente persistentes, para a formação de blocos rochosos bem definidos. A Figura 5 ilus-

Tabela 3. Classificação da Persistência segundo ISRM (1983)

\begin{tabular}{l|l}
\hline TERMO & PERSISTÊNCIA $(\mathrm{m})$ \\
\hline Persistência muito pequena & Menor que 1 \\
\hline Persistência pequena & de 1 a 3 \\
\hline Persistência média & de 3 a 10 \\
\hline Persistência grande & de 10 a 20 \\
\hline Persistência muito grande & maior que 20 \\
\hline
\end{tabular}


tra os aspectos de formação de blocos em função da persistência das descontinuidades.

A orientação espacial, o espaçamento das descontinuidades e a persistência são os principais parâmetros que definirão o formato do bloco típico em cada maciço rochoso, enquanto a existência de conexões entre as descontinuidades pode favorecer o aumento da percolação de água no maciço.

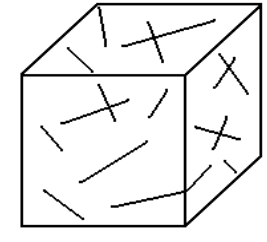

Persistência baixa

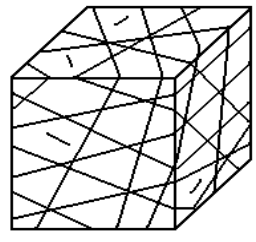

Persistência elevada
Figura 5. Aspectos da formação de blocos em função da persistência de juntas

\subsection{Espaçamento}

Um dos parâmetros mais importantes dentre os que influenciam o comportamento geomecânico e geohidráulico dos maciços rochosos, o espaçamento, ou frequência, procura exprimir a "quantidade" relativa de descontinuidades por unidade de medida, seja em comprimento, área ou volume. Quanto menor for o espaçamento entre as descontinuidades de um maciço, maiores serão as deformações e a permeabilidade. $\mathrm{O}$ espaçamento é determinado em termos da distância média perpendicular entre duas descontinuidades pertencentes à mesma família, sendo as distâncias tomadas geralmente ao longo de linhas de varredura, como por exemplo, uma sondagem ou uma linha de levantamento sistemático de descontinuidades em afloramentos (Brown 1981). O espaçamento pode ser expresso por intervalos de variação numérica. A Tabela 4 contém critérios muito usuais, mas não únicos.

A partir do espaçamento, pode-se determinar um segundo parâmetro dependente denominado

Tabela 4: Espaçamento de descontinuidades (ABGE 1983)

\section{Sigla Espaçamento $(\mathrm{cm})$ Denominação}

\begin{tabular}{l|l|l}
\hline E1 & $>200$ & Muito afastadas \\
\hline E2 & 60 a 200 & Afastadas \\
\hline E3 & 20 a 60 & Medianamente afastadas \\
\hline E4 & 6 a 20 & Próximas \\
\hline E5 & $<6$ & Muito próximas \\
\hline
\end{tabular}

frequência da descontinuidade ou, genericamente, grau de fraturamento do maciço (Müller 1963, apud IPT 1980), uma vez que expressa a quantidade de feições por metro linear de maciço e equivale ao inverso da medida dos espaçamentos, incluindo todos os sistemas presentes. O fraturamento pode ser expresso por graus de intensidade, ao se adotar intervalos de frequência de fraturas, conforme ilustra a Tabela 5, que mostra um critério muito utilizado no Brasil para descrição de fraturamento. Assim como o espaçamento, podem ser adotados outros intervalos de medida.

\subsection{Rugosidade}

A rugosidade corresponde a pequenas variações nas superfícies das descontinuidades, que influenciam especialmente a resistência ao cisalhamento, principalmente no caso de descontinuidades não-preen-

Tabela 5. Graus de fraturamento (IPT 1984)

\begin{tabular}{l|l|l}
\hline \multicolumn{1}{c}{ Siglas } & \multicolumn{1}{l}{ Fraturas/m } & Denominações do maciço \\
\hline F1 & $<1$ & Ocasionalmente fraturado \\
\hline F2 & 1 a 5 & Pouco fraturado \\
\hline F3 & 6 a 10 & Medianamente fraturado \\
\hline F4 & 11 a 20 & Muito fraturado \\
\hline F5 & $>20$ & Extremamente fraturado \\
\hline
\end{tabular}

chidas, conferindo assim um incremento ao ângulo de atrito interno. A Tabela 6 apresenta exemplos de ângulos de atrito para alguns tipos de rochas, a partir dos quais se verifica a ruptura. Além dos valores de ângulo de atrito serem diferentes para cada tipo de rocha, observa-se que os mesmos podem variar de acordo com a situação analisada: rocha intacta, zona de juntas e zonas cisalhadas (ângulo de atrito residual).

As irregularidades no plano de uma descontinuidade podem se manifestar na escala de alguns metros, sendo caracterizadas então como ondulações, ou em dimensões milimétricas a centimétricas, quando recebem o nome de rugosidade ou aspereza. O meio mais prático de quantificar o coeficiente de rugosidade da junta (JRC) é identificar seu perfil geométrico, enquadrando-o nas opções apresentadas na Figura 6.

\subsection{Abertura e preenchimento}

A abertura das descontinuidades é importante no estudo de percolação de água no interior dos maciços rochosos, caracteriza-se como o espaço, vazio ou preenchido por água e/ou outros materiais, que separa as paredes da descontinuidade. As des- 
Tabela 6. Valores de atrito para rochas intactas, juntas e juntas cisalhadas (adaptado de Hoek 1972)

\begin{tabular}{l|l|l|l}
\hline \multirow{2}{*}{ Tipo de Rocha } & \multicolumn{3}{|c}{ Ângulo de Atrito interno (graus) } \\
\cline { 2 - 4 } & Intacta & Junta & Residual \\
\hline Andesito & 45 & $31-35$ & $28-30$ \\
\hline Basalto & $48-50$ & 47 & - \\
\hline Gesso & - & $35-41$ & - \\
\hline Diorito & $53-55$ & - & - \\
\hline Granito & $50-64$ & - & $31-33$ \\
\hline Grauvaca & $45-50$ & - & - \\
\hline Calcário & $30-60$ & - & $33-37$ \\
\hline Monzonito & $48-65$ & - & $28-32$ \\
\hline Pórfiro & - & 40 & $30-34$ \\
\hline Quartzito & 64 & 44 & $26-34$ \\
\hline Arenito & $45-50$ & $27-38$ & $25-34$ \\
\hline Xisto & $26-70$ & - & - \\
\hline Folhelho & $45-64$ & 37 & $27-32$ \\
\hline Siltito & 50 & 43 & - \\
\hline Ardósia & $45-60$ & - & $24-34$ \\
\hline
\end{tabular}

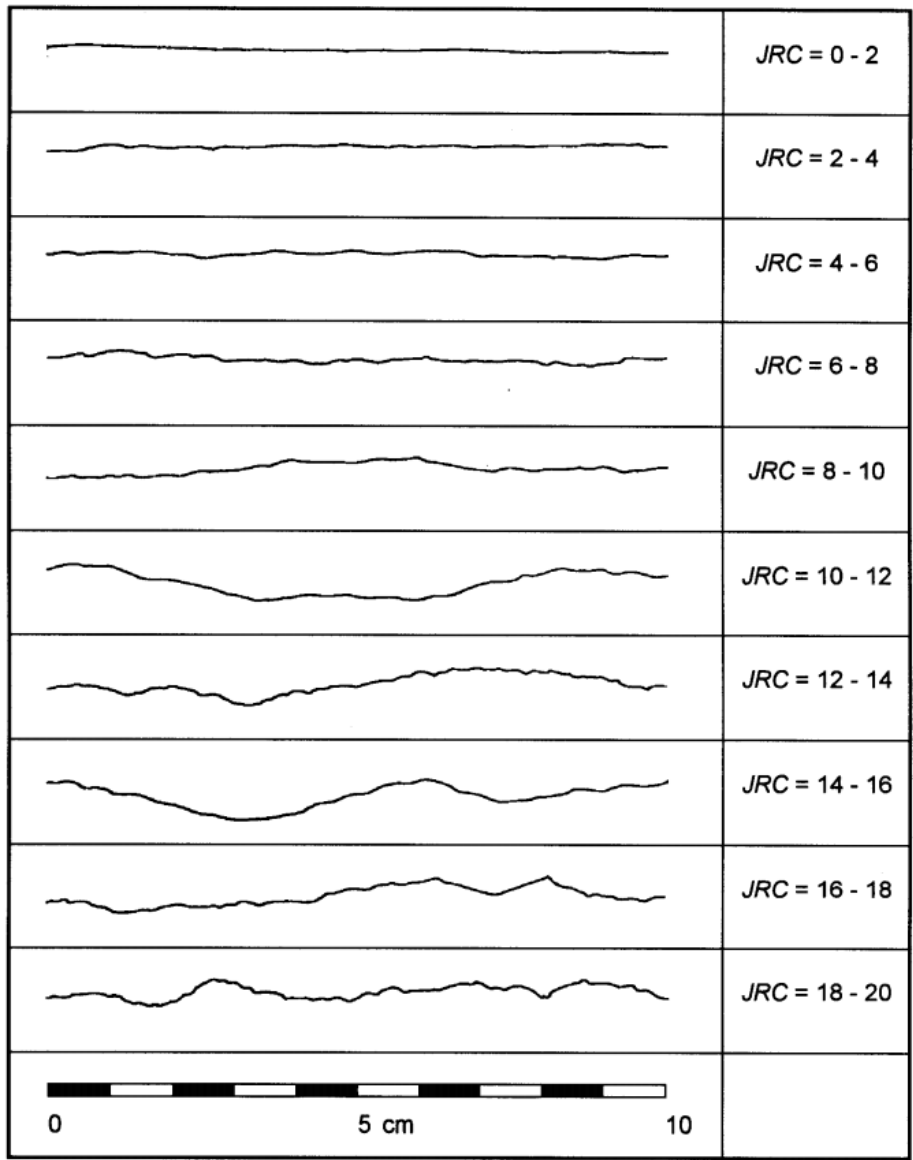

Figura 6. Perfis de rugosidade para a determinação de coeficientes de rugosidade (Barton e Choubey 1977) continuidades podem ser classificadas como fechadas, abertas ou preenchidas, mas nem sempre é possível realizar, com precisão, uma observação direta. Ensaios de permeabilidade constituem técnica eficiente para se avaliar o grau de abertura (ISRM 1983, p. 81). A abertura de uma junta não necessariamente está relacionada com sua abertura original, uma vez que esta pode ter sido modificada posteriormente à formação, como ocorre no processo de erosão e/ou soerguimento de maciços.

O preenchimento é importante porque, dependendo da espessura, pode controlar ou modificar a resistência ao cisalhamento e a percolação de água nas descontinuidades. Se as paredes opostas da descontinuidade não se tocam e o preenchimento ocupa todo o espaço vazio entre elas, a resistência, a deformabilidade e a permeabilidade do material que preenche a fratura condicionam o comportamento do maciço rochoso em geral.

Em regiões tropicais, como no Brasil, uma fonte importante dos preenchimentos das descontinuidades consiste na decomposição intempérica da própria rocha vizinha à fratura, formando padrões geométricos intrincados complexos, a complexidade dependerá dos arranjos espaciais da trama de juntas e do grau de intemperismo das superfícies postas em contato pelas juntas.

\subsection{Percolação de água nas descontinuidades}

Em maciços rochosos em que a "porosidade" é essencialmente dependente de fraturas, as descontinuidades desempenham papel de grande importância no escoamento. Por esse motivo o fluxo que percola no maciço rochoso está ligado às descontinuidades presentes. É muito importante levar em conta os diversos tipos litológicos, pois as descontinuidades estão ligadas à gênese e aos esforços a que estas foram submetidas durante sua formação ou mesmo em eventos posteriores. O conheci- 
mento das propriedades dos maciços e, principalmente, de suas descontinuidades, é extremamente importante para o estudo de percolação de água nos meios fraturados. Os principais parâmetros que influenciam o escoamento são:

- orientação espacial das famílias de descontinuidades (atitudes);

- abertura das descontinuidades;

- espaçamento das descontinuidades;

- rugosidade absoluta das paredes.

Dentro dos parâmetros mencionados acima, a abertura e a rugosidade são considerados os de maior importância no estudo de escoamento em meios fraturados. O fluxo dentro dessas descontinuidades será mais bem descrito a seguir.

\subsubsection{Fluxo em maciços rochosos}

Maciços rochosos são cortados por famílias de descontinuidades, cada uma com sua atitude, distribuição espacial e abertura, dessa forma, não é conveniente tratar as fraturas presentes no maciço de forma individual, a não ser em situações demasiadamente específicas, e de grande detalhe, nas quais uma determinada feição crítica possa ser decisiva para a estabilidade de uma porção restrita de uma encosta. Para se determinar os parâmetros hidráulicos dos maciços são utilizados basicamente dois métodos: amostragens de fraturas e ensaios hidráulicos de campo.

O primeiro método é baseado na obtenção de informações a respeito dos sistemas de fraturas do maciço (número de famílias, orientação, abertura, espaçamento etc.), a partir dos quais, por determinação analítica, é obtido um tensor de permeabilidade, ou seja, a determinação no espaço dos módulos e direções principais. O principal problema do método mencionado acima é a própria obtenção de medidas representativas do sistema de fraturamento.

O método de ensaios hidráulicos em campo baseia-se em resultados de ensaios de bombeamento ou injeção d'água, nos quais os resultados do ensaio integram as influências individuais dos vários parâmetros presentes no sistema de fraturas. A maior dificuldade associada a esse método é a determinação de um volume de ensaio que seja representativo do maciço rochoso. Atualmente, o método que parece ser mais promissor, e que apresenta melhores resultados, consiste na injeção ou bombeamento de água em um trecho de um furo e observação dos furos vizinhos. Para execução do ensaio não é necessário conhecer as direções princi- pais do fraturamento, do mesmo modo, os furos de ensaio podem ser executados em qualquer direção e os volumes utilizados no ensaio podem ser controlados pela escolha do espaçamento entre os furos de injeção e os de observação. O método também é capaz de detectar a presença, nas proximidades da região de ensaio, de uma feição muito impermeável ou muito permeável, não interceptadas a princípio pelos furos de ensaio (Quadros 1992).

Em casos mais simples, e para avaliações menos precisas da permeabilidade nos maciços rochosos, pode-se utilizar a seguinte equação:

$$
\mathrm{K}_{\mathrm{M}}=\frac{\mathrm{e}}{\mathrm{l}} \mathrm{K}_{\mathrm{f}}+\mathrm{K}_{\mathrm{r}}
$$

Sendo:

$\mathrm{K}_{\mathrm{M}}=$ permeabilidade do maciço rochoso;

$\mathrm{e}=$ abertura das descontinuidades;

$1=$ espaçamento entre as descontinuidades;

$\mathrm{K}_{\mathrm{f}}=$ permeabilidade das fraturas

$\mathrm{K}_{\mathrm{r}}=$ permeabilidade da matriz rochosa.

Uma vez que a permeabilidade da matriz rochosa é muito baixa, esta pode ser desprezada e, levando-se em conta as equações propostas por Poiseuille para fluxo entre duas placas paralelas, a equação anterior pode ser reescrita da seguinte maneira:

$$
K_{M}=\frac{g \cdot e^{3}}{12 v l}
$$

Sendo:

$\mathrm{K}_{\mathrm{M}}$ = permeabilidade do maciço rochoso;

$\mathrm{g}=$ aceleração da gravidade;

$\mathrm{e}=$ abertura das descontinuidades;

$\mathrm{v}=$ viscosidade dinâmica da água;

$1=$ espaçamento entre as descontinuidades.

$\mathrm{Na}$ prática, a determinação da abertura das fraturas de um maciço rochoso é extremamente difícil. Neste caso, pode ser usado o conceito de transmissividade $(\mathrm{T}=\mathrm{K} . \mathrm{b})$, determinada por meio de ensaios de bombeamento in situ, que tem a vantagem de eliminar a determinação imprecisa tanto de (e) quanto de $\left(\mathrm{K}_{\mathrm{f}}\right)$. Admite-se assim que a espessura saturada do meio (b) corresponde à abertura equivalente das fraturas. Em vários casos práticos, a permeabilidade dos maciços é estimada a partir de ensaios pontuais de permeabilidade (perda d'água sob pressão, infiltração, etc.) obtendo-se assim valores de condutividade elétrica equivalente. 


\section{Arranjos geométricos e interseções de descontinuidades}

A interseção e a orientação espacial de diferentes sistemas de descontinuidades, principalmente juntas, determinam a formação de blocos rochosos, sendo esta a estrutura elementar dos maciços e, potencialmente, da queda de blocos. A orientação dos sistemas de descontinuidades em relação à geometria da superfície de corte de um talude, por exemplo, pode indicar se os blocos são instáveis ou não. A presença de estruturas penetrativas, ou seja, estruturas que se repetem de maneira persistente no interior do maciço, como a estratificação reliquiar ou foliações metamórficas, pode servir como referência para determinação da orientação de outras descontinuidades planares.

A forma resultante da interseção dos sistemas de fraturas presentes em um maciço rochoso, no espaço tridimensional define, segundo Ruhland (1973), o bloco unitário, ou bloco elementar. O arranjo é dependente da frequência das fraturas e sua posição espacial. Müller (1963, apud IPT 1980) classifica os blocos unitários médios dos maciços com base na relação entre os espaçamentos médios dos sistemas (d) e o maior valor de espaçamento observado $\left(\mathrm{d}_{\max }\right)$.

O volume do bloco unitário médio é dado pela multiplicação dos três parâmetros (Müller 1963, apud IPT 1980):

$$
V=d_{1} \cdot d_{2} \cdot d_{3}
$$

Esse tipo de análise constitui um modo quantitativo de correlacionar as fraturas e seu arranjo por unidade de volume, condicionados pelos demais fatores que interferem na frequência e espaçamento das fraturas, como o tipo litológico, a presença de outras estruturas como estratificação, foliações etc.

\section{Análise regional de fraturamento}

O problema da regionalização de dados de juntas a partir de dados estruturais tem motivado muitas investigações teórico-práticas e de campo que buscam estabelecer abordagens eficientes para se interpretar a trama interna de um maciço rochoso, a partir da coleta de dados pontuais. O problema de se definir, em um dado local, padrões, caracteres distintivos das famílias de juntas presentes e homogeneidade do maciço rochoso não é simples (IPT 1980), nem se pode afirmar que esteja resolvido de maneira inequívoca, apesar do evidente interesse prático dessa linha de estudos, que permitiria ações eficazes de planejamento de cortes, fundações, túneis, escavações em geral e até mesmo implantação de aterros em encostas dominadas por rochas fraturadas. A primeira dificuldade resulta do problema, bem conhecido, imposto pela qualidade dos afloramentos.

Dentre os parâmetros de caracterização de descontinuidades descritos no capítulo anterior e mencionados acima, é frequente, em estudos regionais de fraturamento, que o geólogo concentre sua atenção na coleta de dados no parâmetro que parece ser mais importante: a orientação dos planos de juntas (Ramsay e Huber 1987), mas é preciso ter em mente de que esta constitui somente o primeiro passo da investigação, uma vez que as demais propriedades das fraturas pode interferir decisivamente no comportamento mecânico do maciço.

Tabela 7. Classificação de blocos unitários médios (Modif. Müller 1963, apud IPT 1980)

\begin{tabular}{c|c|c|c|c|c|}
\hline $\begin{array}{c}\text { Forma do bloco } \\
\text { unitário } \mathbf{d}(\mathbf{c m})\end{array}$ & $\mathbf{d}_{\mathbf{1}}=\mathbf{d}_{2}<<\mathbf{d}_{3}$ & $\mathbf{d}_{\mathbf{1}}=\mathbf{d}_{2}<\mathbf{d}_{3}$ & $\mathbf{d} \mathbf{1}=\mathbf{d} \mathbf{2}=\mathbf{d} \mathbf{3}$ & $\mathbf{d} \mathbf{1}=\mathbf{d} \mathbf{2}>\mathbf{d} \mathbf{3}$ & $\mathbf{d}_{\mathbf{1}}=\mathbf{d}_{2}>>\mathbf{d}_{3}$ \\
\hline $\mathrm{d}_{1} / \mathrm{d}_{2}, \mathrm{~d}_{2} / \mathrm{d}_{3}$ & $<1: 5$ & $1: 2 \mathrm{a} 1: 5$ & $\sim 1: 1$ & $2: 1$ a $5: 1$ & $>5: 1$ \\
\hline $\mathrm{d}_{\max }>100$ & Grande coluna & $\begin{array}{c}\text { Grande prisma } \\
\text { alongado }\end{array}$ & Grande cubo & $\begin{array}{c}\text { Grande prisma } \\
\text { achatado }\end{array}$ & Grande placa \\
\hline $100>\mathrm{d}_{\max }>10$ & Média coluna & $\begin{array}{c}\text { Médio prisma } \\
\text { alongado }\end{array}$ & Médio cubo & $\begin{array}{c}\text { Médio prisma } \\
\text { achatado }\end{array}$ & Média placa \\
\hline $\mathrm{dmax}_{\operatorname{man}}<10$ & Pequena coluna & $\begin{array}{c}\text { Pequeno prisma } \\
\text { alongado }\end{array}$ & Pequeno cubo & $\begin{array}{c}\text { Pequeno pris- } \\
\text { ma achatado }\end{array}$ & Pequena placa \\
\hline
\end{tabular}




\section{Tratamento de dados estruturais}

Os dados estruturais requeridos na análise de estabilidade de maciços rochosos estão ligados a estruturas planares como falhas, fraturas, acamamento, xistosidade etc. e dados lineares, como linhas de interseção de planos, estrias de atrito em falhas, eixos de dobras, dentre outros. Para representação e tratamento desses dados utiliza-se a projeção estereográfica, que permite representar as orientações espaciais dos dados estruturais e facilita a visualização tridimensional. Possibilita, ainda, realizar diversas operações, importantes no estudo de estabilidade de taludes.

Deve-se ter em mente que a projeção estereográfica utilizada para a projeção de estruturas planares ou lineares no estudo de vertentes e taludes deve ser o Diagrama de Igual Área, também denominado de Rede de Schmidt-Lambert, ou simplesmente rede de Schmidt, por permitir um tratamento estatístico da distribuição de dados. Um erro muito comum realizado por estudantes e até mesmo por profissionais da área de geologia de engenharia no estudo estatístico de vertentes e taludes consiste na utilização da projeção estereográfica de igual ângulo, também denominado Diagrama de Wulff. Dados de polos, quando lançados nesse diagrama não sofrem alteração quanto à orientação geográfica, porém a disposição dos dados estruturais sofre dispersão junto ás bordas do diagrama e concentração na parte central, o que pode levar a interpretações equivocadas.

Existem três maneiras distintas de se representar os dados planares no Diagrama de Igual Área. Um plano pode ser representado por sua projeção ciclográfica, que consiste em um círculo máximo (linha c) (Fig. 7). Um plano também pode ser representado por apenas um ponto no diagrama de Schmidt-Lambert, sendo esta a sua projeção polar, bastante útil para quando se dispuser de grande número de dados. Para representação desse ponto, também chamado de polo (ponto P na Figura 7), basta contar 90 graus a partir do ciclograma do plano, passando pelo centro do diagrama. Outra forma de representação de um plano é pelo rumo de mergulho. O rumo de mergulho (ponto R na Fig. 7) é a linha de máxima inclinação do plano e perpendicular à sua direção. Essa forma é bastante adequada para estudos de estabilidade de taludes, pela vantagem de permitir visualização imediata da direção e do sentido de movimentação ao longo do plano potencial de escorregamento.

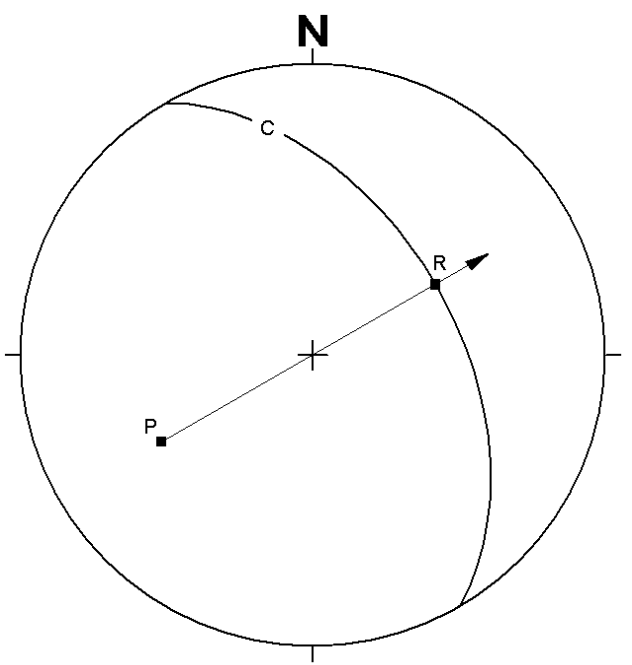

Figura 7. Formas de representação de um plano no Diagrama de Schmidt-Lambert. P é a projeção polar do plano, c é sua projeção ciclográfica (ciclograma) e R é a projeção da reta pendente do mergulho

Uma forma bastante simples e rápida de lançar rumos de mergulho e polos de planos é pela utilização do Diagrama Polar, que constitui modificação do Diagrama de Schmidt-Lambert, sua principal característica é agilizar o procedimento de representação dos dados estruturais. O diagrama não permite a representação ciclográfica de planos, sendo necessária a plotagem dos planos no Diagrama de Schmidt-Lambert para análise cinemática dos maciços rochosos.

A descrição detalhada das operações possíveis com estereogramas de dados estruturais podem ser consultados em Ragan (1973), Hobbs et al. (1976), Loczy e Ladeira (1976), Hasui e Mioto (1992), Davis e Reynolds (1996), Carneiro et al. (1996) e Leyshon e Lisle (1996) que descrevem, em detalhes, as operações possíveis com os diagramas e algumas interpretações.

A análise estrutural busca recompor a trama macroscópica, a partir de elementos estruturais, reconhecidos nas demais escalas de abordagem (meso- e microscópica) (Carneiro 1983). Um requisito da análise estrutural é a delimitação mais ou menos precisa de domínios homogêneos, que são porções do corpo em que existe orientação relativamente uniforme de determinada(s) feição(ões) ou estrutura(s). Um domínio não precisa ser necessariamente homogêneo em relação a todas as estruturas observáveis. Raramente a homogeneidade na escala macroscópica é demonstrável por simples inspeção (Turner e Weiss 1963, p. 147).

Certos procedimentos devem ser adotados 
para que o mapeamento estrutural seja eficiente e mostre a existência, ou não, de homogeneidade estatística:

- Coletam-se dados em diferentes estações uniformemente distribuídas na superfície do terreno a ser analisado, dentro das limitações impostas pela natureza.

- Escolhe-se um número pequeno de domínios, contendo o maior número de estações com padrões simples ou uniformes de descontinuidades presentes no afloramento ou no mapa.

- Constroem-se diagramas de orientação para cada conjunto de estruturas presentes, por domínio. No diagrama, se houver orientações preferenciais unimodais, isso revela que o domínio é homogêneo com relação à estrutura correspondente.

- Por inspeção visual e produção de diagramas estereográficos, subdivide-se cada domínio até que os subdomínios resultantes sejam tão uniformes quanto possível.

Depois que os dados estruturais são plotados, vários estudos podem ser feitos para investigar a estabilidade de taludes, em diferentes domínios estruturais, determinando-se áreas críticas que requerem análise pormenorizada, especialmente para elaboração de projetos de engenharia. A análise por projeção estereográfica não leva em conta os efeitos da água nas descontinuidades, ou a coesão, altura da vertente, e outros parâmetros intimamente ligados à estabilidade das vertentes, entretanto, é possível incorporar parâmetros muito importantes nos estudos, como o ângulo de atrito das descontinuidades e a atitude das vertentes.

\section{Regionalização de dados estruturais}

Santoro et al. (1979) desenvolveram um método de regionalização de dados de fraturamento de maciços rochosos para a região dos Morros de Santos e São Vicente, apoiados em cartografia geológica (Carneiro et al. 1979) e geomorfológica (Pires Neto et al. 1979).

O método envolve: (a) demarcação de domínios homogêneos e de análise de dados estruturais, (b) tratamento estatístico de dados de orientação de juntas e falhas, obtidos em diversas estações de amostragem espalhadas pela região estudada, (c) identificação de fotolineamentos em fotos aéreas de detalhe, (d) teste de campo, (e) reconhecimento dos padrões regionais, que foram denominados "tendências do fraturamento".

Sistemas preferenciais ocorrem quando a mesma orientação espacial aparece com frequência expressiva nos dados estruturais medidos (Santoro et. al. 1979), um sistema preferencial é persistente quando o conjunto de estruturas medidas possui a mesma orientação espacial em mais de uma estação de amostragem. Quando determinado intervalo de orientação de fotolineamentos está presente com maior frequência do que outros, ele define quantitativamente um máximo de rosácea. Finalmente, uma tendência dominante de fraturamento é definida quando houver boa correlação entre o cruzamento de dados de sistemas preferenciais persistentes com os máximos de rosáceas. A técnica permite prever o padrão de fraturamento das rochas (com graus de certeza variáveis entre alto, regular e baixo) e extrapolar as informações para áreas adjacentes ou mesmo zonas não-aflorantes.

A literatura é rica em relatos de casos e exemplos de aplicação de análise estrutural de descontinuidades em campos variados, tais como: exploração mineral, pesquisa de hidrocarbonetos, hidrogeologia e geotecnia. Muitos estudos de análise estrutural em estudos neotectônicos buscam determinar paleotensões (Neves e Morales 2001, Hancock e Engelder 1989).

Santana et al. (2003) investigaram a utilização de imagens Landsat/TM para diagnóstico de fatores geológico-estruturais que influenciam o modelado do relevo. $\mathrm{Na}$ abordagem morfotectônica que desenvolveram, o tratamento estatístico de dados de lineamentos possibilita detectar zonas mais suscetíveis à incidência de movimentos de massa na região da Serra do Mar.

\section{Análise de estabilidade de encostas}

Muitos blocos em taludes escavados em rocha se encontram em condições estáveis, mesmo contendo planos de fraqueza bem inclinados. Normalmente isso ocorre porque as condições locais de atrito na base dos blocos são altas ou não há liberdade de movimento ao longo das superfícies de fraqueza que os delimitam; tais fatores impedem assim a movimentação. Entretanto, uma vez retirado o impedimento por erosão, escavação, ou crescimento de fraturas maiores, o bloco (ou os blocos) ficará(ão) livre(s) e deslizará(ão).

A análise de estabilidade de blocos tem por base as atitudes dos planos de fraqueza em relação à atitude da vertente ou do talude, levando-se em con- 
sideração nessa análise o ângulo de atrito atuante ao longo desses planos. Identificar modelos potenciais de escorregamento é de grande importância para a análise de estabilidade e posterior tratamento de taludes. De modo geral, os escorregamentos em maciços rochosos podem ser classificados em três tipos principais: escorregamentos planares, escorregamentos em cunha e tombamento de blocos.

A Figura 8 ilustra os quatro tipos de rupturas mais comuns em maciços rochosos determinadas por descontinuidades, que podem condicionar diretamente o mecanismo e a geometria da ruptura.
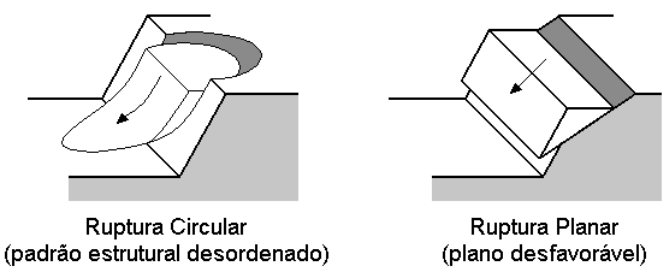

Ruptura Planar (plano desfavorável)

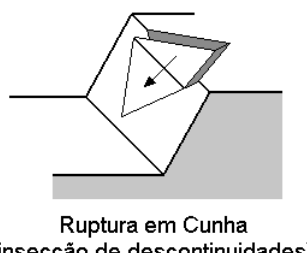

(insecção de descontinuidades)

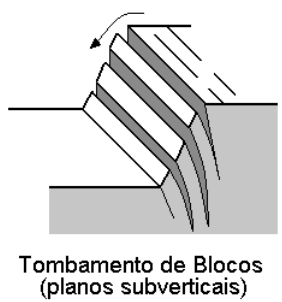

Figura 8. Tipos de ruptura decorrentes da distribuição espacial das descontinuidades em maciços rochosos (Modif. de Hoek e Londe 1974, Piteau e Martin 1981)

$\mathrm{Na}$ análise de estabilidade de uma vertente é importante identificar em campo as estruturas que representam planos potenciais de ruptura e eliminar aqueles que provavelmente não serão envolvidos em deslizamentos.

\section{Critério de ruptura de Mohr-Coulomb}

Na natureza não existe o predomínio de um único modo de ruptura de rochas. Processos de deformação como flexura, cisalhamento, tensão, compressão etc. podem provocar ruptura.

A flexura refere-se ao processo de ruptura quando a rocha é submetida a uma flexão, como desenvolvimento e propagação de juntas de tração. Esses tipos de rupturas são comuns em taludes de rocha constituídos por camadas com altos mergulhos, quando blocos podem rotacionar e cair, caracterizando assim um tombamento de blocos (toppling failure).

A ruptura por cisalhamento está ligada à formação de uma superfície de ruptura na qual o esforço cisalhante atinge um valor crítico, seguido de um deslocamento ao longo do plano de ruptura e relaxamento do esforço em questão. Esse tipo de ruptura é muito comum em taludes escavados em rochas pouco resistentes, como argilitos, folhelhos e rochas trituradas em zonas de falhas.

A ruptura por tração pode ocorrer em rochas situadas próximas à superfície ou em vertentes, como por exemplo, nos flancos de anticlinais. $\mathrm{O}$ fenômeno é muito comum em granitos, gnaisses e migmatitos, quando os planos de ruptura dispostos subparalelamente à superfície são chamados de fraturas de alívio de carga ou juntas de esfoliação. Quando associadas a taludes ou vertentes bastante inclinadas, podem levar à queda de blocos.

O critério de ruptura mais conhecido e mais simples é o critério de Mohr-Coulomb, que consiste de uma linha envoltória, que pode ser curvilínea ou retilínea, dependendo da rocha, tangenciando o círculo de Mohr, e que representa as condições críticas de combinações dos esforços principais (Fig. 9).

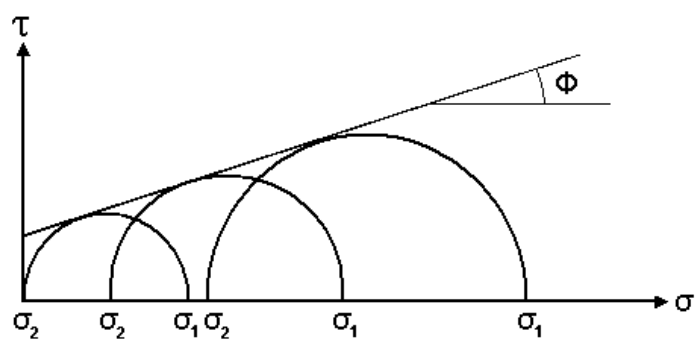

Figura 9. Critério de ruptura de Mohr-Coulomb

Para rochas, a equação dessa reta é dada por:

$$
\tau=c+\sigma_{n} \operatorname{tg} \Phi
$$

Onde $\tau$ representa o pico do esforço cisalhante ou o pico de resistência ao cisalhamento, $\Phi$ é o ângulo de atrito interno ou ângulo de atrito entre duas superfícies, c é a coesão e $\sigma_{n}$ é a componente do esforço que atua perpendicularmente ao plano de ruptura. O critério de ruptura de Mohr-Coulomb também é usado para representar a resistência residual ao esforço, ou seja, o esforço mínimo oferecido pelo material após o pico de deformação. 


\section{Escorregamento ao longo de estruturas planares}

Escorregamentos planares envolvem deslocamento de massas de rochas e solos ao longo de superfícies subparalelas entre si (Fiori e Carmignari 2009), não é necessário que o escorregamento afete uma estrutura do corpo de rocha, como planos de acamamento, foliação, falhas ou juntas, para que seja considerado planar: basta que a superfície de deslizamento seja aproximadamente formada por um plano.

Para que o escorregamento ocorra, as estruturas devem ser aflorantes e inclinadas na direção da face livre da vertente, com ângulo superior ao ângulo de atrito interno da rocha e ângulo menor que o da inclinação da superfície livre da vertente. O deslizamento ocorrerá ao longo da direção de mergulho, admitindo-se uma variação de $20^{\circ} \mathrm{em}$ torno da direção. As dimensões das estruturas planares podem variar desde juntas menores, que controlam deslizamentos de blocos de dezenas a centenas de metros cúbicos, até grandes deslizamentos translacionais, que envolvem deslizamento de blocos de dezenas de milhares de metros cúbicos de rocha.

A presença de água subterrânea em taludes instáveis, nos planos de descontinuidades, ou nas fendas dos blocos rochosos, pode afetar a estabilidade do maciço rochoso. A água nos planos de descontinuidade favorece o deslizamento, ao reduzir a resistência ao cisalhamento, ao passo que, se estiver acumulada em fendas de tração pode aumentar as forças mobilizantes. Além disso, a água acelera o processo de intemperismo, levando à progressiva perda da resistência do material. Onde houver a possibilidade de deslizamentos planares é importante controlar não somente a água subterrânea, mas também a água superficial.

Para que um deslizamento planar ocorra, três condições básicas devem ser observadas:

- Em condições sem água no sistema, o ângulo de mergulho do plano de deslizamento deve ser maior que o ângulo de atrito do plano;

- A direção do deslizamento deverá variar de, no máximo, $20^{\circ}$ em relação ao rumo de mergulho da vertente;

- O plano de deslizamento deve aflorar na face livre da vertente.

A Figura 10 mostra uma vertente instável pelas condições básicas acima: o plano de ruptura (representado em vermelho) se encontra dentro da área sombreada entre o plano representativo da face da vertente e o círculo do ângulo de atrito $\Phi$.

\section{Deslizamento em cunha}

Deslizamentos em cunha estão relacionados a escorregamentos translacionais ao longo de pelo menos dois conjuntos de planos que se cruzam. As orientações dos dois conjuntos são críticas para condicionar escorregamentos em cunha, sendo necessário que a linha de interseção (que representa a direção efetiva do deslocamento) aflore na face livre do talude com ângulo de inclinação maior que o ângulo de atrito interno da rocha (Fiori e Carmignari 2009).

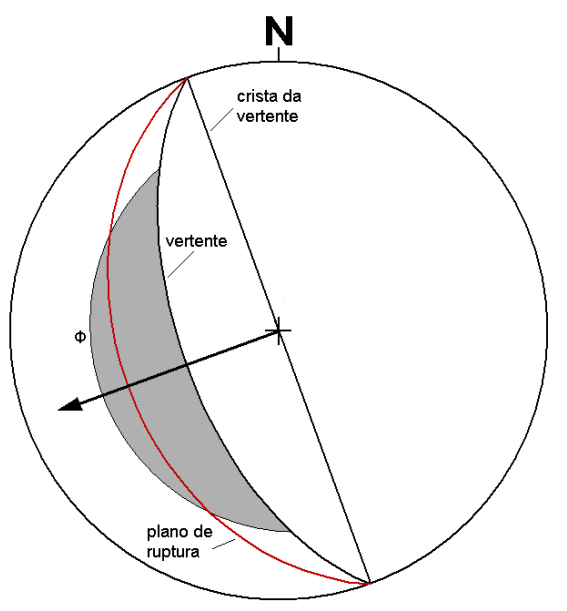

Figura 10. A área sombreada representa as possíveis direções de deslizamento, características de uma ruptura planar ao longo da vertente representada (Adapt. Fiori e Carmignari 2009)

As forças mobilizantes e resistentes atuantes no deslizamento em cunha requerem análises mais detalhadas do que as envolvidas em escorregamentos planares. Se os planos de inclinação são muito diferentes, a força normal atuante em cada um também será diferente. Além disso, os planos podem apresentar diferentes valores de resistência ao deslocamento. A presença de água no sistema, da mesma forma que no caso anterior, pode levar à instabilização da cunha pela ação do aumento da pressão ao longo dos planos de deslocamento. Para que ocorra um deslizamento em cunha, três condições básicas devem ser observadas em campo:

- As superfícies envolvidas no deslizamento devem se cruzar ou aflorar na face livre da vertente;

- A linha de interseção dos planos envolvidos deverá aflorar na vertente; 
- O ângulo de mergulho da linha de interseção deverá ser maior que o ângulo de atrito dos planos envolvidos.

Uma vertente é potencialmente instável quando a linha de intersecção dos dois planos que delimitam uma cunha cai dentro da área sombreada entre o plano de atitude da vertente e o círculo do ângulo de atrito $\Phi$, conforme a Figura 11. Deve-se ater ao fato de que o método utilizado serve tanto para rupturas planares como rupturas em cunha, porque uma ruptura planar pode ser considerada como sendo um caso especial de ruptura em cunha, na qual a atitude dos dois planos é a mesma.

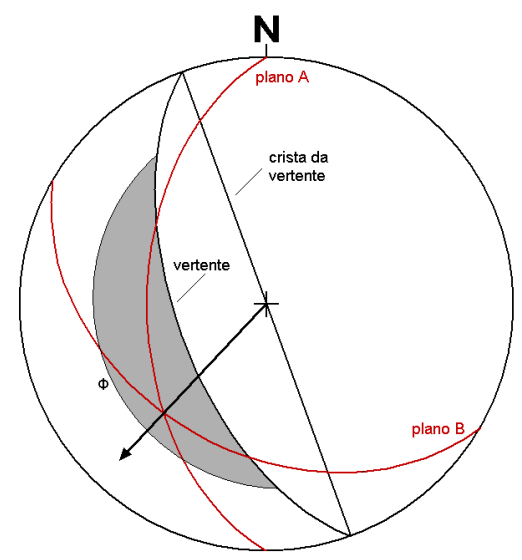

Figura 11. Um deslizamento em cunha deverá ocorrer quando a linha de interseção dos planos A e B for maior que o ângulo de atrito $\Phi$ e menor que 0 mergulho aparente da face da vertente (Adapt. Fiori e Carmignari 2009)

\section{Tombamento de blocos}

O processo de tombamento de blocos (toppling) envolve mecanismos diferentes de movimentação das massas rochosas, não ligados à algum tipo de escorregamento (Fiori e Carmignari 2009). Blocos individuais, ou conjunto de blocos, sofrem uma rotação sobre eixos fixos, tombando assim na face livre da vertente. Para que ocorra o tombamento de blocos, é essencial a presença de planos estruturais bem definidos como acamamento, xistosidade, falhas, juntas etc. As condições mais favoráveis aparecem quando duas famílias de descontinuidades se cruzam, uma delas mergulhando com altos ângulos e contra a face livre da vertente e a outra com baixos ângulos, no mesmo sentido da vertente (Markland 1972, Hoek e Bray 1981).

Para que o tombamento de bloco ocorra, são necessárias as seguintes condições:

- Haver duas famílias de descontinuidades que se cruzam, inclinadas uma favor e outra contra a inclinação da face livre da vertente;

- As condições mais favoráveis para tombamento de blocos ocorrem quando a família da descontinuidade que mergulha contra a vertente é inclinada a ângulos altos $(90-\Phi)$ (Hoek e Bray 1981), enquanto a família que mergulha a favor da vertente deverá apresentar inclinações menores que o ângulo de atrito interno (Fig. 12).

- O sentido de mergulho dos planos deverá se localizar dentro de $20^{\circ}$ do sentido de mergulho da face da vertente.

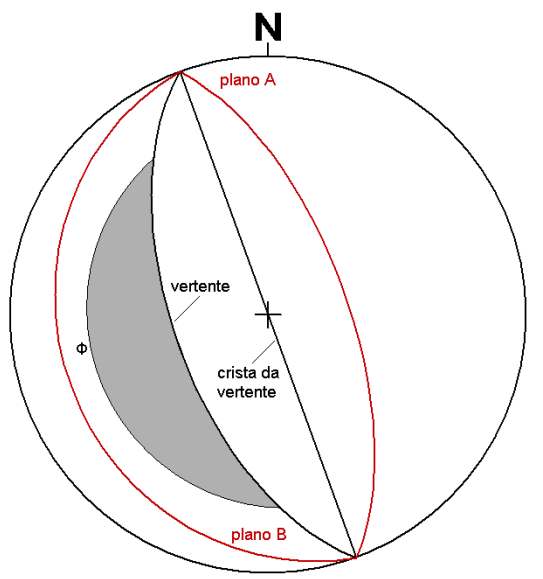

Figura 12. Interpretação de dois conjuntos de descontinuidades, sendo um com ângulo fortemente inclinado e mergulhando contra a vertente (plano A) e outro, pouco inclinado e mergulhando a favor da vertente com ângulo de mergulho menor que $\Phi$ (plano B) (Adapt. Fiori e Carmignari 2009)

\section{Análise de estabilidade de maciços rochosos}

A análise de estabilidade de maciços rochosos envolve um conjunto de procedimentos, que visam à determinação de um índice (uma grandeza) que permita quantificar o quão próximo este se encontra da ruptura, dentro de determinado conjunto de condicionantes. Métodos analíticos, empregando o equilíbrio limite, expressam a estabilidade de um talude rochoso por um Coeficiente ou Fator de Segurança. (CS, ou FS), como visto na Tabela 8. Os coeficientes são calculados pelo quociente entre a resistência e as forças motoras envolvidas, ao longo da superfície de movimentação.

A adoção de determinado valor de FS, em um projeto de implantação ou contenção de taludes rochosos, depende de vários fatores, entre os quais se destacam as consequências potenciais associadas à instabilização do talude (área urbana, estrada, 
Tabela 8. Fatores de segurança e respectivas condições de estabilidade do talude (Carvalho 1991)

\begin{tabular}{l|l}
\hline \multicolumn{1}{c|}{ Fator de segurança (FS) } & \multicolumn{1}{c}{ Condição do talude } \\
\hline FS $<1,0$ & Talude instável, deverá sofrer ruptura. \\
\hline FS $=1,0$ & $\begin{array}{l}\text { Condição limite de estabilidade associada à iminência de ruptura, também, } \\
\text { condição adotada geralmente nos cálculos de retroanálise. }\end{array}$ \\
\hline FS $>1,0$ (pouco maior) & $\begin{array}{l}\text { Condição estável, quanto mais próximo de } 1,0 \text { for o FS, mais precária e } \\
\text { frágil será a condição de estabilidade do talude. }\end{array}$ \\
\hline FS $>1,0$ (muito maior) & $\begin{array}{l}\text { Condição estável, quanto maior for o FS, menores serão as possibilidades } \\
\text { de o talude vir a sofrer ruptura quando submetido a condições críticas } \\
\text { (percolação d'água etc.). }\end{array}$ \\
\hline
\end{tabular}

mineração etc.), a dimensão do talude, a heterogeneidade do maciço, a base de dados utilizada etc. A Figura 13 exemplifica formulação do tipo equilíbrio-limite para o cálculo do FS de uma ruptura planar de um maciço rochoso, considerando, inclusive, a ação de um tirante.

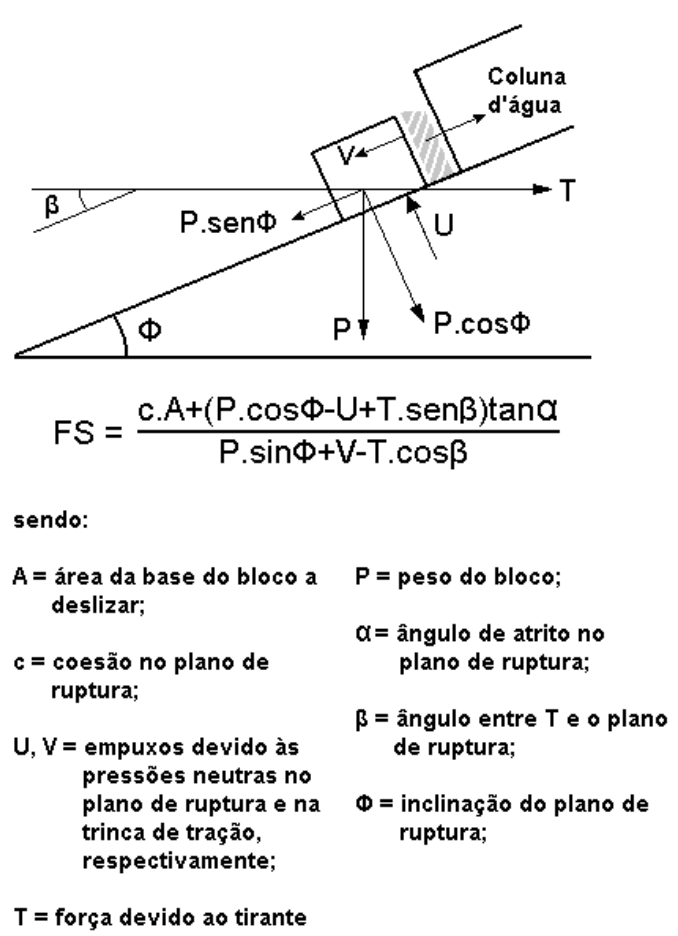

Figura 13. Exemplo de formulação do tipo equilíbrio-limite para o calculo do FS em uma ruptura planar de um maciço rochoso (Modif. Augusto Fo. e Virgili 1981)

Um conceito útil na aplicação de métodos de equilíbrio-limite para a análise de estabilidade de um bloco é a ideia de resistência disponível e resistência mobilizada. Desse modo, o fator de segurança contra o escorregamento, ao longo de uma superfície, pode ser expresso como a razão entre a resistência ao cisalhamento disponível e o esforço cisalhante mobilizado. A resistência ao cisalhamento mobilizada deverá ser igual à tensão cisalhante aplicada, sendo assim, o fator pode ser expresso como (Hoek e Bray 1981):

$$
F_{s}=\frac{\operatorname{tg} \phi \text { disponível }}{\mathrm{g} \phi \text { mobilizado }}
$$

Sendo, por exemplo:

$\Phi$ disponível: o ângulo de atrito verificado para um determinado plano de escorregamento ou tipo de material e;

$\Phi$ mobilizado: o ângulo de atrito correspondente a um conjunto de forças atuantes sobre o bloco.

Os métodos analíticos que utilizam as relações de tensão-deformação necessitam o conhecimento das resistências ao cisalhamento de pico e residuais, e do estado de tensões iniciais do maciço. Um aspecto básico dos métodos analíticos, sejam eles do tipo equilíbrio-limite ou do tipo tensão-deformação, consiste na seleção adequada dos valores dos parâmetros envolvidos no cálculo de FS (pressões neutras, ângulo de atrito, coesão, peso específico etc).

\section{Retroanálise}

O método denominado retroanálise se caracteriza como um caso de "problema inverso", uma vez que proporciona uma avaliação dos parâmetros que dizem respeito a um modelo particular onde já foi deflagrado um problema de origem geológica-geotécnica (tal como tombamentos de blocos, rupturas de taludes rochosos ou de solos etc.), a fim de que se verifique se a estrutura do modelo apresentado é ou não adequado à resolução do 
problema e determinação de suas causas.

Nos casos em que se usa a retroanálise, são feitas tentativas de cálculo do fator de segurança, até se ajustar os parâmetros de resistência (coesão e ângulo de atrito) à condição de FS $=1,0$. Os cálculos levam em conta as condições geométricas, geotécnicas e hidrogeológicas durante o processo de ruptura. Deve-se tomar a devida atenção nesse método porque os parâmetros adotados correspondem à resistência média do talude como um todo.

Uma das aplicações mais úteis do método é a avaliação do ganho de segurança com a execução de uma obra de estabilização do talude, rompido ou em processo de ruptura. Os parâmetros de resistência são obtidos por retroanálise e então se calcula a melhoria no fator de segurança a ser obtido com realização da obra, seja uma drenagem, uma estrutura de contenção, etc. Mello (1972) sugere que o método é mais confiável e mais preciso do que o cálculo dos fatores de segurança em termos absolutos.

\section{Obras de estabilização}

\subsection{Injeções de maciços rochosos}

Injeções em maciços rochosos têm como finalidade principal sua consolidação ou impermeabilização. Se, por um lado, injeções de impermeabilização ou de vedação são mais utilizados em barragens, as injeções de consolidação são mais empregadas nos maciços rochosos de fundações e taludes. Uma vez que os maciços podem se apresentar muito fraturados, a injeção de impermeabilização é efetuada antes da escavação a partir da frente a ser escavada. Injeções também são utilizadas em casos em que é preciso consolidar materiais soltos para se evitar desabamentos.

\subsection{Dreno horizontal profundo}

Drenos horizontais profundos, ou DHPs como são mais conhecidos, servem para drenar camadas ou feições de um maciço rochoso. Geralmente são utilizados individualmente devido ao efeito localizado, mas podem ser utilizados em maior número e com espaçamento variado.

Os DHPs têm como objetivo estabelecer comunicação entre a pressão atmosférica e a pressão interna do maciço rochoso, permitindo aliviar eventual pressão do aquífero a uma distância conveniente da face da vertente (como talude de cortes, por exemplo). A técnica introduz uma melhoria imediata na estabilidade.

Para melhor eficiência, os DHPs devem ser colocados no maciço de modo que a extensão imersa do tubo filtrante no aquífero seja a maior possível, levando-se em conta o conhecimento prévio da presença de aquíferos livres e potenciais aquíferos confinados. O comprimento dos drenos não ultrapassa $50 \mathrm{~m}$, sendo mais comum a presença de drenos de 10 a $20 \mathrm{~m}$.

\subsection{Ancoragens}

Ancoragens introduzem um elemento resistente, por meio de perfuração no maciço natural, com o objetivo conter deformações ou deslocamentos do maciço, melhorando assim sua resistência. Existem dois tipos de ancoragens: as ativas, que recebem o nome de tirantes, e as passivas, sendo conhecidas como chumbadores.

Os chumbadores são geralmente utilizados como sistemas de suporte temporário, mas podem ser empregados em sistemas definitivos contanto que sejam permitidas as deformações necessárias para que o sistema seja eficaz. Chumbadores podem ser utilizados para contenção de blocos de rocha, reforço de paredes de escavações ou na fixação de telas metálicas em concreto projetado, dutos e outras estruturas.

Os tirantes, quando utilizados em sistemas temporários, evitam as quedas de blocos de rocha das paredes de escavações, bem como podem fazer contenção de blocos ou cunhas de rochas, isoladas por fraturas ou conjunto de fraturas. Quando usados em sistemas de suporte definitivo são dispostos de forma sistemática, em malha geométrica, conseguindo-se assim um sistema de rocha comprimida logo atrás da superfície de escavação ou encosta, contendo os eventuais deslocamentos ou deformações no maciço rochoso.

\section{Estudo de caso no granito Santos, SP}

$\mathrm{Na}$ Baixada Santista, a zona limítrofe dos municípios de Santos e São Vicente é marcada pela presença de saliências topográficas sustentadas por rochas relacionadas ao Complexo Costeiro (Hasui e Sadowski 1976) e corpos ígneos mais jovens. No complexo predominam gnaisses e migmatitos oftalmíticos e estromatíticos, possivelmente formados antes do Ciclo Brasiliano, sob condições tectônicas intensas que levaram à formação de bandamento 
migmatítico, dobramentos, redobramentos, transposição de estruturas e aparecimento de longas zonas lineares formadas por rochas miloníticas.

No Ciclo Brasiliano a intensa deformação regional foi responsável por migmatização, recristalização de milonitos, redobramento e aparecimento de corpos de rochas granitóides porfiróides. A posterior deformação de rochas granitóides porfiróides ocorreu juntamente com a recristalização de rochas cataclásticas e miloníticas antigas, processo que deu origem, dentre outros tipos litológicos, a blastomilonitos. Junto com a inflexão geral das estruturas, formaram-se ondulações que exibem eixos fortemente inclinados (Carneiro et al. 1979). No final do Ciclo Brasiliano intrudiram-se, nas rochas regionais, massas de um granito isótropo rosado que formou o Granito Santos (Carneiro et al. 1979).

O Granito Santos, por ser o tipo litológico mais resistente à ação da erosão, sustenta a maior parte das áreas acima de $150 \mathrm{~m}$ de altitude nos morros de Santos e São Vicente.

Diferentes tipos de dobras, descontinuidades e foliações (estratificação reliquiar, xistosidade, gnaissosidade, bandamento, clivagem e foliação cataclástica) estão presentes nas rochas. O estudo das geometrias, associações e superposições permite definir sucessivas fases de deformação, metamorfismo, migmatização e magmatismo (Carneiro et al. 1979). O tectonismo tardio deformou tanto as rochas antigas como o Granito Santos, formando zonas de falhamento transcorrente. Com idade ainda incerta, o soerguimento que acompanhou a fase de estabilização tectônica regional propiciou o desenvolvimento de sistemas de juntas.

Os diques de diabásio e numerosas falhas normais que cortam as rochas proterozoicas são relacionadas à tectônica mesozoica-cenozoica. Os diques fazem parte de enxames orientados subparalelamente à linha de costa (Almeida 1986), encontrados em toda a região costeira, paulista e carioca, nas zonas compreendidas entre as serras do Mar e Mantiqueira. Completando o quadro geológico da área são encontradas coberturas sedimentares marinhas, de ambiente de transição, aluviais e coluviais presentes nas unidades quaternárias.

\section{Geologia local}

As unidades rochosas de interesse direto para o presente trabalho são descritas com base em Carneiro et al. (1979):
- Granito Santos: é um granito a duas micas, intrusivo, não-orientado (Fig. 14), de coloração cinza, ocasionalmente bege a róseo e granulação fina a média. O maciço sustenta os morros de Santa Terezinha, José Menino e Voturuá. Apresenta microclina micropertítica, quartzo e oligoclásio como minerais principais, biotita e muscovita como minerais acessórios, e zircão, epídoto e opacos em menor quantidade. A textura característica é granular hipidiomórfica.

Aplitos e pegmatitos seccionam tanto o maciço rochoso como as demais unidades encaixantes (Fig. 15). Os pegmatitos se apresentam zonados, com bordas aplíticas e núcleos grossos: cristais de muscovita e feldspato tendem a se alongar perpendicularmente às paredes de muitos diques $\mathrm{e}$ veios. Foram descritas concentrações irregulares de granada idioblástica que podem estar dispostas ao longo de superfícies paralelas às paredes de corpos tabulares (Carneiro et al. 1979).

Falhas transcorrentes do final do Ciclo Brasiliano cortam o Granito Santos e outras rochas proterozoicas. As zonas de cisalhamento assim formadas controlam a orientação geral de alguns trechos de encostas, como p.ex. um extenso segmento do Morro do Marapé, situado a certa distância do limite NNE da área de estudo. Falhas de gravidade cenozoicas desenvolveram-se por ativação das falhas antigas, sendo associadas a fraturamento intenso. A movimentação gerou cataclasitos restritos, dispostos ao longo de planos de fraturas subverticais. Concordantes com esses planos, foram mapeadas intrusões máficas

- Rochas intrusivas básicas: são encontradas nas proximidades das zonas de cisalhamento associadas a falhas reativadas. São corpos intrusivos, tabulares e subverticais, com espessuras variando entre alguns centímetros até poucos metros. Os maiores corpos podem ser encontrados na Ilha Porchat e na Pedreira Atlântica, no Morro Santa Terezinha, onde foram reconhecidos lamprófiros portadores de fenocristais de olivina em massa fina de augita, com carbonatos, zeólitas e clorita como minerais secundários, que haviam sido mapeados por Sadowski (1974) como ultrameláfiros ankaratríticos, uma questão discutida por Carneiro et al. (1979).

O fraturamento das rochas do Morro de Santos merece atenção especial devido à sua influência nos mecanismos de deslocamento de blocos. Para Carneiro et al. (1979) existem pelo menos três gera- 


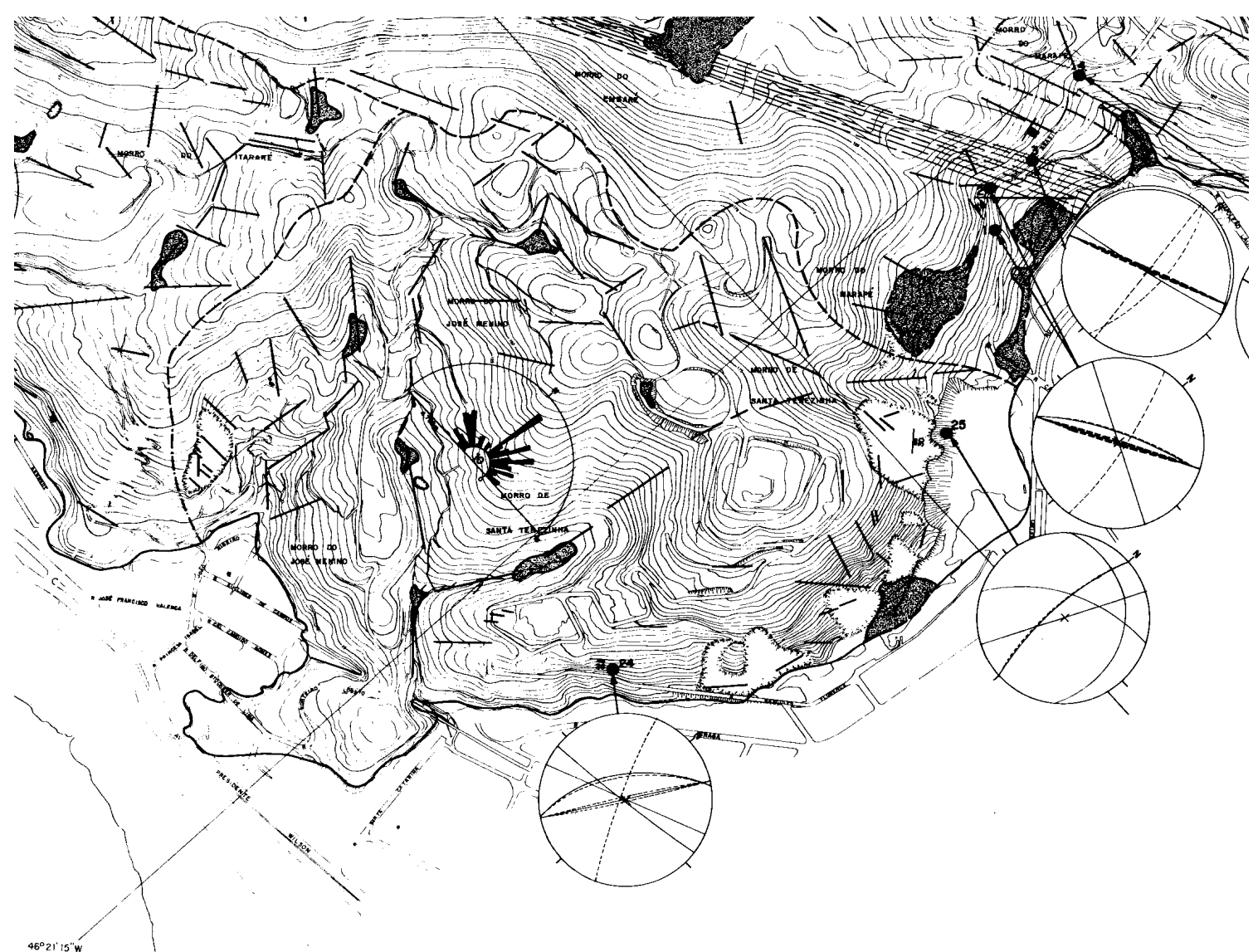

Figura 14. Mapa estrutural do Morro Santa Terezinha contendo os sistemas preferenciais persistentes de descontinuidades e a rosácea de fotlineamentos dessa unidade de análise (Santoro et. al. 1979)

ções de juntas: a mais antiga, anterior à atividade granitóide embrechítica, afeta o melanossoma de migmatitos; a segunda geração de juntas, regional, corta todas as unidades litológicas, inclusive o Granito Santos; a terceira geração de fraturas está relacionada ao episódio de formação das zonas de cisalhamento, que cortam todas as sequências anteriores. Nestas zonas, uma vez que houve deslocamento, muitas juntas evoluíram para falhas.

No Morro Santa Terezinha (Fig. 14), os sistemas de descontinuidades mostram a seguinte tendência dominante: N25E vertical (115/90 ou 295/90 na notação Clar), N30E 70NW (300/70 em Clar) e N05E 85NW (285/85), em ordem decrescente de certeza na determinação das tendências (Santoro et. al. 1979). As duas primeiras tendências foram obtidas devido a uma boa correlação (grau de certeza alto), ao passo que a terceira tendência foi estabelecida com grau de certeza regular. Na rosácea ainda aparece um intervalo entre $\mathrm{N} 46-60 \mathrm{~W}$, que não se correlaciona com nenhum dos sistemas de fraturas presentes nas estações. Pode-se presumir que tal sistema esteja presente na parte $\mathrm{W}$ do maciço, não tendo sido detectada essa orientação de fraturas (Santoro et. al. 1979) porque o local fica distante das estações de amostragem do mapeamento de meados de 1978.

\section{Geologia da encosta do Morro Santa Terezinha}

A caracterização geológica local da encosta nordeste do Morro Santa Terezinha (MoST) foi possível a partir do mapeamento estrutural do maciço por rapel, técnica que permitiu o acesso às porções subverticais da encosta. Os dados foram coletados pelo geólogo André Stern com ajuda da estagiária Michelly de Paula da Rocha e gentilmente cedidos pela empresa Bureau de Projetos e Consultoria Ltda. (Bureau 2010) para o presente trabalho.

O principal tipo litológico do maciço é dado pelo Granito Santos, uma rocha plutônica maciça, sem orientação (Fig. 15), sem alteração significativa, podendo ser considerada rocha sã ou RS (terminologia IPT 1984), grau de coerência C1 (Guidicini et al. 1972), e granulação fina a média, que apresenta mineralogia composta de biotita (15\%), 


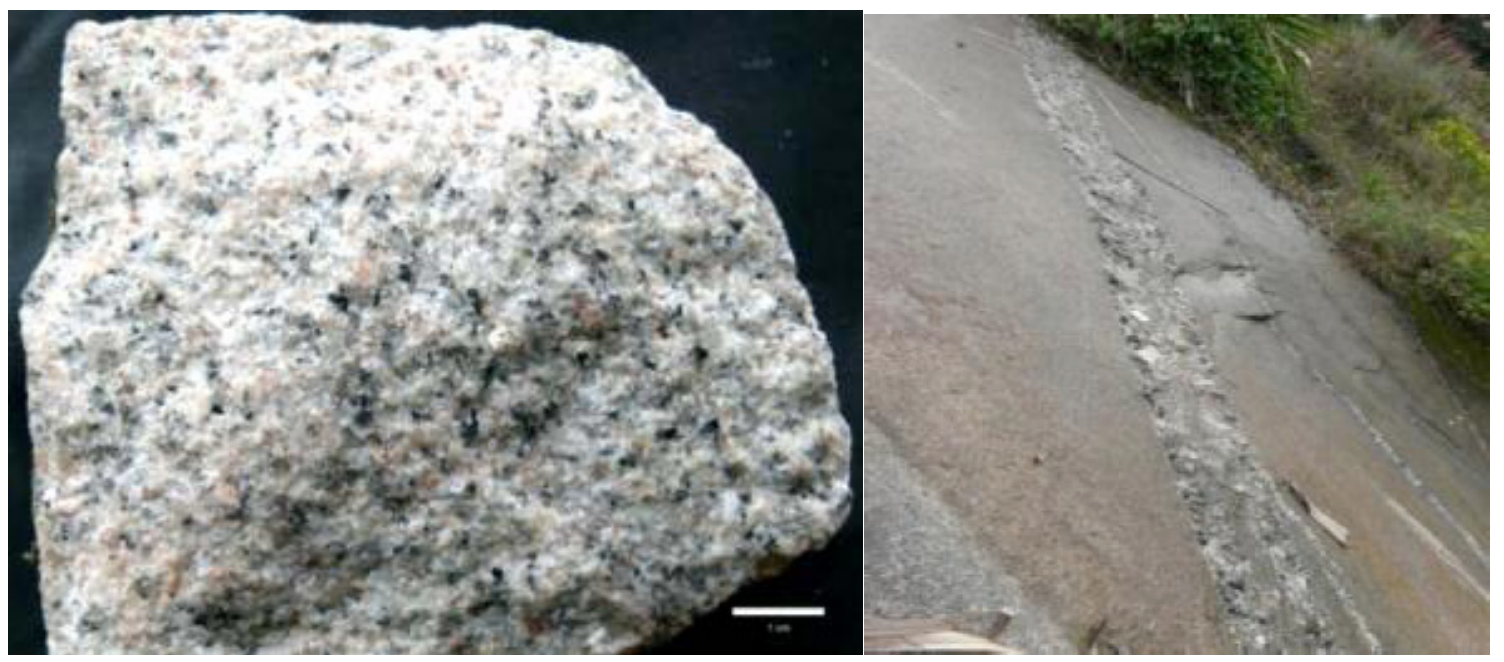

Figura 15. Aspecto mesoscópico do Granito Santos (a), veio pegmatítico que corta o Granito Santos (b)

quartzo (40\%) e feldspato (45\%). A resistência à compressão simples da rocha é superior a $100 \mathrm{Mpa}$ (Bureau 2010). O Granito Santos é cortado por veios pegmatíticos e aplíticos, cuja orientação não corresponde a qualquer descontinuidade rúptil presente no maciço. Nas proximidades do emboque do reservatório da Sabesp, pode ser encontrado de forma localizada um dique intrusivo de diabásio, associado a zonas de cisalhamento mais recentes (posteriores à intrusão do Granito Santos), apresentando forma tabular, oblíqua, com mergulho subvertical e espessura aparente de aproximadamente 3 m (Fig. 16).

\section{Geologia Estrutural}

As medidas das descontinuidades estruturais foram feitas in situ por meio de vias de rapel. Foram obtidas 332 medidas de atidudes de juntas e falhas tectônicas, apresentando duas famílias principais NW-SE subvertical e NE-SW vertical (Fig. 17). Em relação a juntas de esfoliação (planos que podem dar ao granito um aspecto de "casca de cebola", ver Fig. 2) foram coletadas 217 medidas, obtendo-se atitude concordante com o mergulho geral da encosta do maciço granítico. As medidas são respectivamente apresentadas nas tabelas 9 e 10. Se por um lado existe a limitação causada pelo fato de que os autores do levantamento não distinguem atitudes de juntas em geral das atitudes de falhas, a separação dos dados de juntas de esfoliação constitui importante passo para interpretação dos sistemas presentes. Os dados de fraturas em geral e falhas apresentam-se com notável dispersão, mas isso não se aplica aos diagramas de medidas estruturais de juntas de esfoliação, nos quais a concentração unimodal de dados reflete um predomínio da direção NW-SE (Fig. 18) e mergulho regular para NE. Tais elementos revelam a razoável regularidade dos planos de esfoliação.
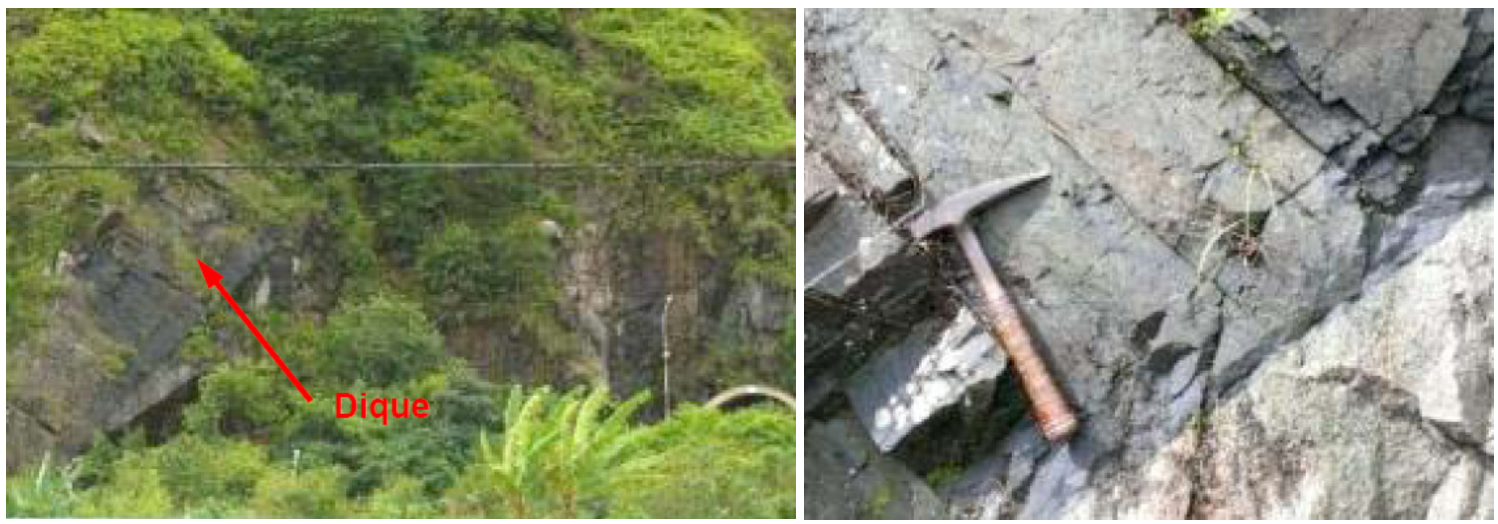

Figura 16. Dique de diabásio em corte de estrada: (a) visão geral, (b) diáclases perpendiculares às paredes 

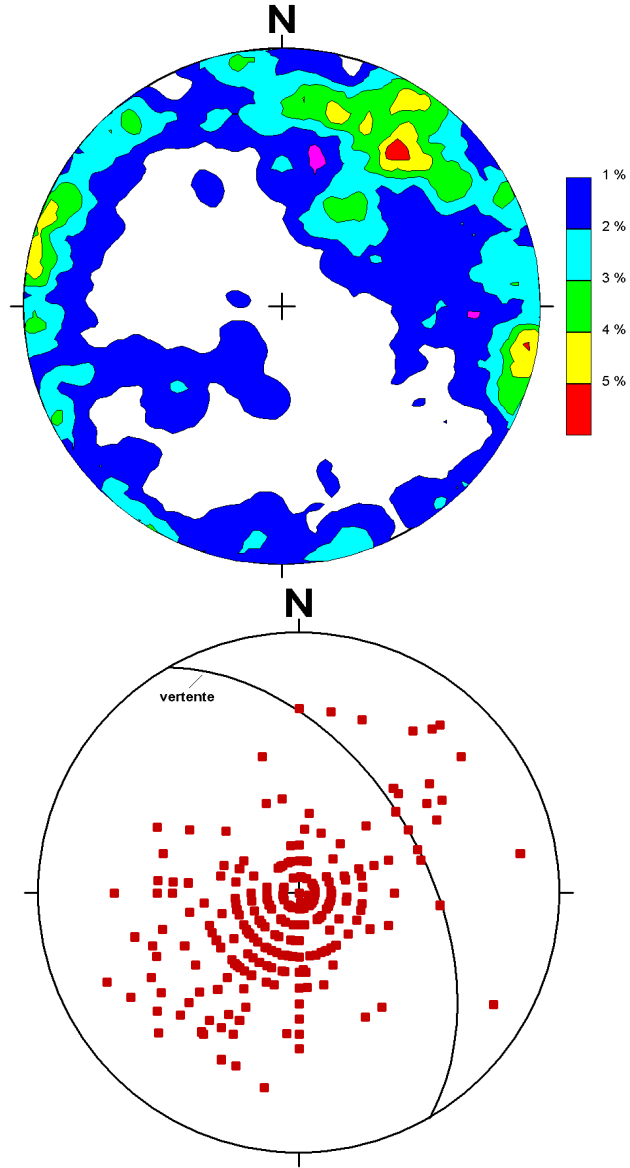

Figura 17. Diagramas de Schmidt das medidas estruturais de juntas em geral e falhas: (a) concentração de polos, (b) orientação da vertente e projeções polares das retas pendentes de mergulho de cada fratura

Os dados coletados em campo na encosta estudada correlacionam-se de modo significativo com os sistemas preferenciais identificados por Santoro et al. (1979). Alguma diferença existe em função de que as estações de amostragem de dados em 1978 situam-se na base da encosta, enquanto os novos dados foram coletados ao longo da encosta e nas porções mais altas via rapel. No projeto Bureau (2010) foi realizado levantamento topográfico pela empresa S\&C Serviços de Medição e Modelamento Ltda., sendo usado equipamento de scanner laser Leica HDS. A nuvem de pontos obtida serviu para confecção de malha tridimensional da encosta, uma vez que não era possível o acesso à área com equipamentos convencionais (Fig. 19).

O levantamento in situ incluiu elaboração de mapa estrutural (Bureau 2010) do Morro Santa Terezinha, do qual foi extraída a Figura 20.

Os dados mostram que o Granito Santos possui sistemas de descontinuidades regularmente orientados, observáveis na encosta. A ilustração não
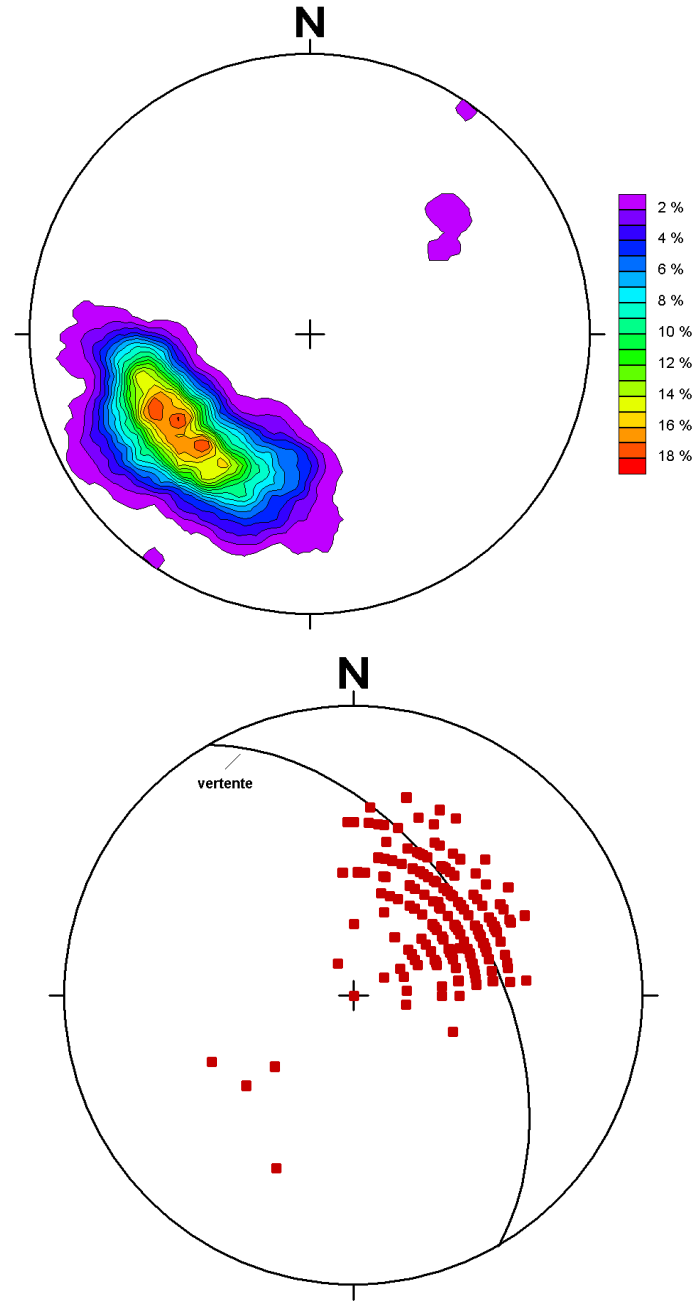

Figura 18. Diagramas de Schmidt das medidas estruturais de juntas de esfoliação: (a) concentração de polos, (b) vertente e projeções polares das retas pendentes de mergulho de cada junta de esfoliação

discrimina atitudes de juntas de esfoliação, tendo sido interpretados os dados de fraturas presentes segundo três famílias, a saber:

- Sistema principal de fraturas (A): apresenta direção média N30E e mergulhos entre 60 o e 80 o.

- Sistema secundário de fraturas (B): direção média N60W e mergulho vertical.

- Sistema terciário de fraturas $(\mathrm{C})$ : direção entre $\mathrm{N}-\mathrm{S}$ e N05E e mergulhos entre $60^{\circ}$ e $80^{\circ}$.

No presente estudo, as estruturas do Morro Santa Terezinha foram reinterpretadas, utilizando-se exclusivamente dados do levantamento estrutural in situ (Bureau 2010) (Fig. 20). O diagrama da Figura 21 reune os dados de campo. Pode-se afirmar que os sistemas de fraturas adiante discutidos possuem orientação distinta das três famílias 


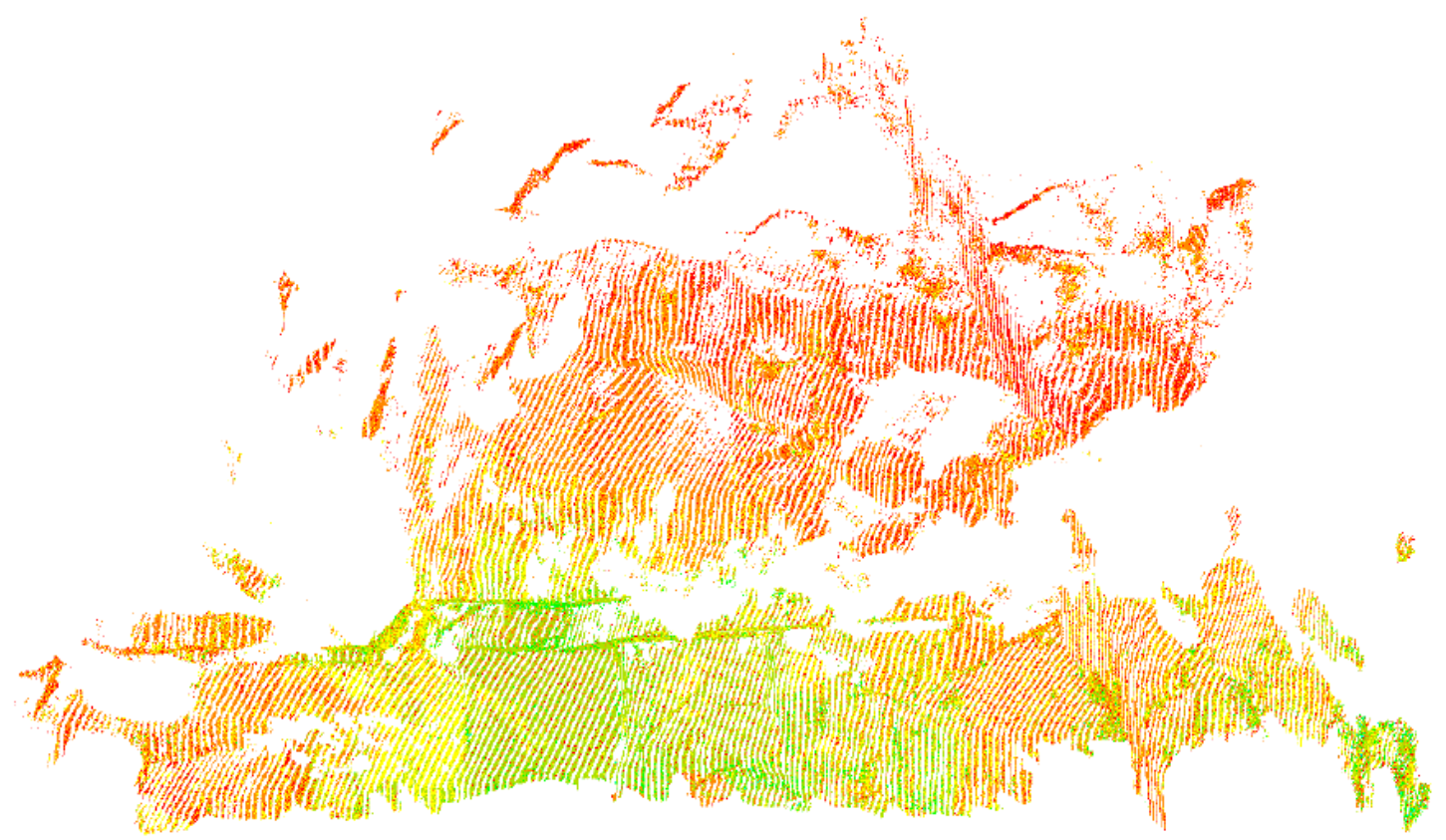

Figura 19. Nuvem de pontos gerada a partir da vista frontal da encosta nordeste do Morro Santa Terezinha

Figura 20. Mapa estrutural do Morro Santa Terezinha (Modif. de Bureau 2010). Os sistemas de fraturas identificados são referidos como: principal (A), secundário (B) e terciário (C)

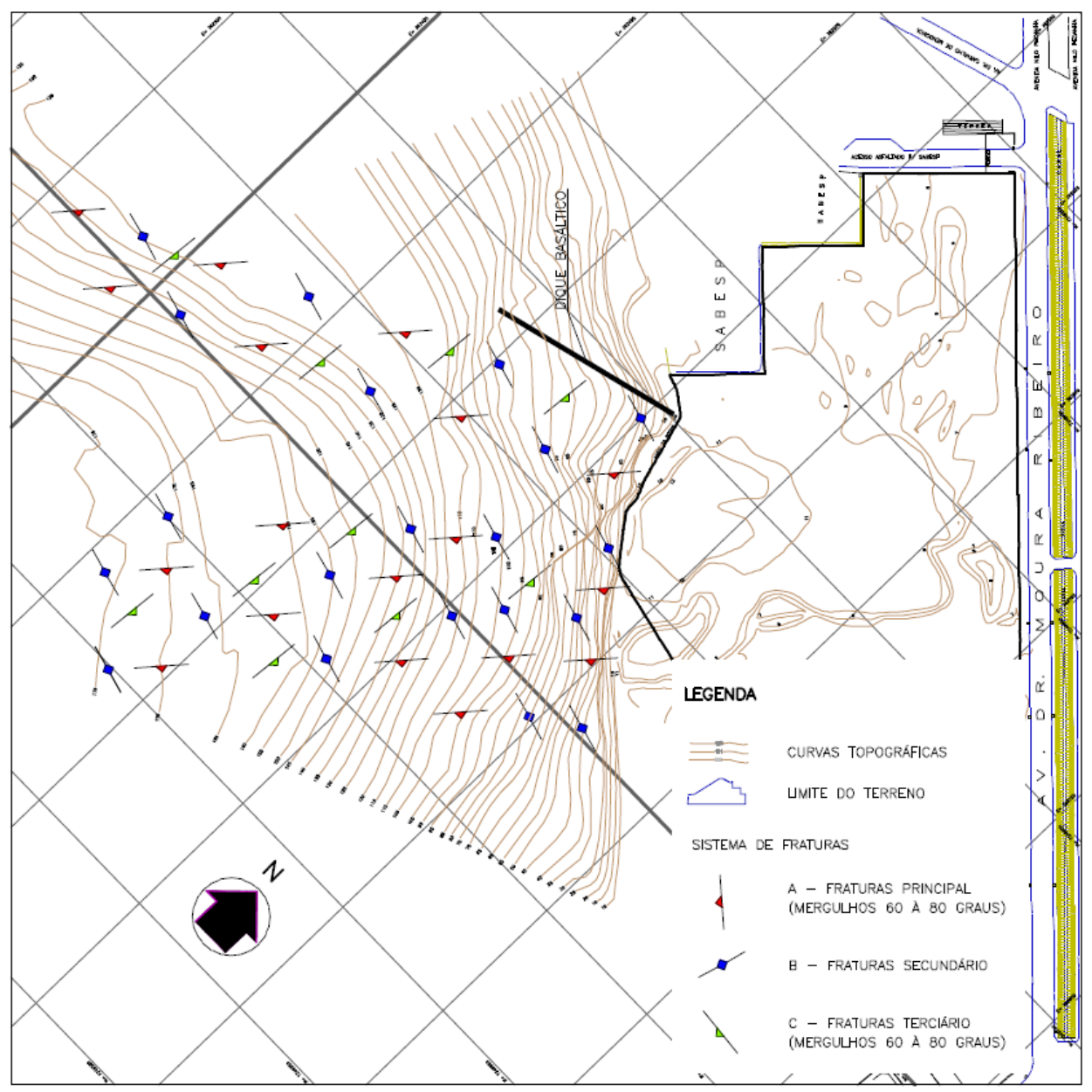


de fraturas acima referidas (Bureau 2010), sendo claramente dominados pelas juntas de esfoliação.

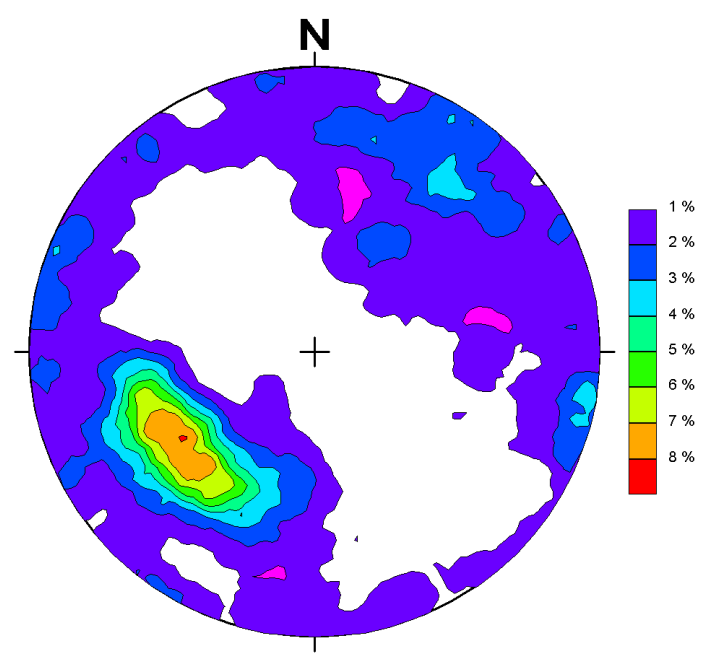

Figura 21. Diagrama de Schmidt do conjunto de 549 medidas estruturais da encosta do Morro Santa Terezinha, compreendendo juntas em geral, falhas e juntas de esfoliação. A concentração dominante de polos corresponde às juntas de esfoliação

De acordo com o tratamento estatístico realizado no programa Stereonet (Figs. 21 e 22), nota-se que a atitude das juntas de esfoliação $(A=057 / 47$, em notação Clar) pode ser considerada um sistema preferencial na porção estudada do maciço granítico. Possivelmente, em outras porções das encostas situadas nesse corpo granítico, a orientação das juntas de esfoliação poderá ser bem diferente. Por outro lado, para falhas e juntas, foram encontrados no presente trabalho os seguintes sistemas preferenciais persistentes de descontinuidades: $\mathrm{B}$ : 216/64, C: $110 / 87$ e D: 289/85. As estruturas encontradas em campo podem ser referidas do seguinte modo (Fig. 22):

- Sistema de juntas de esfoliação: direção média N30W e mergulhos entre $40^{\circ}$ e $50^{\circ}$.

- Sistema de fraturas B: direção média N60W e mergulhos entre $60^{\circ}$ e $70^{\circ}$.

- Sistema de fraturas C: direção média N20E e mergulho vertical.

- Sistema de fraturas D: direção média N10E e mergulho vertical.

O pequeno intervalo de variação dos mergulhos, subverticais, permite considerar os sistemas de fraturas C e D como representantes da mesma família. É plena a correlação dessas atitudes com os sistemas de fraturamento e tendências dominantes definidos por Santoro et al. (1979), corroborando o alto grau de certeza representado pela tendência N25E vert. Além disso, foi visualizado um novo sistema preferencial de fraturamento $(B=216 / 64)$. Santoro et. al (1979), não haviam detectado esse sistema preferencial, porém sua existência fôra admitida na porção W do domínio em função do máximo 3a de rosácea. O intervalo N46-60W corresponde precisamente ao sistema preferencial $\mathrm{B}$.

A distância observada entre as fraturas e descontinuidades é em média de $1 \mathrm{~m}$, em poucos locais, onde há maior concentração de falhas e ou fraturas, o espaçamento é menor.
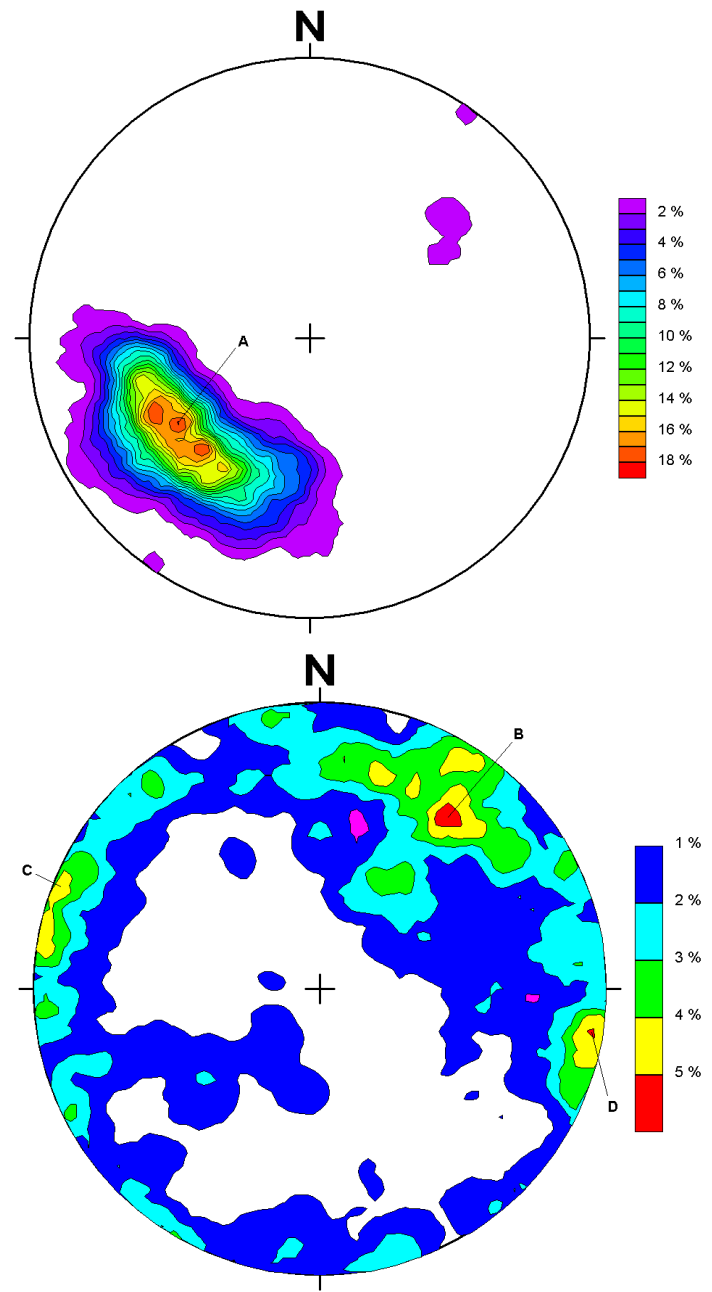

Figura 22. Tratamento estatístico realizado com Stereonet: (a) tratamento estatístico dos dados de juntas de esfoliação mostrando a atitude preferencial A:57/47, (b) tratamento estatístico dos dados de fraturas e falhas apresentando as atitudes preferenciais C:110/87 e D:289/85 (citadas por Santoro et. al. 1979) e o novo sistema preferencial B:216/64 
Tabela 9. Dados de juntas e falhas

\begin{tabular}{|c|c|c|c|c|c|c|c|c|c|}
\hline $117 / 65$ & $220 / 90$ & $45 / 75$ & $70 / 50$ & $220 / 70$ & $190 / 70$ & $200 / 70$ & $170 / 90$ & $234 / 35$ & $115 / 80$ \\
\hline $175 / 65$ & $214 / 80$ & $15 / 80$ & $345 / 45$ & $225 / 70$ & $25 / 90$ & $190 / 70$ & $115 / 85$ & $214 / 35$ & $145 / 70$ \\
\hline $177 / 66$ & $95 / 45$ & $05 / 85$ & $80 / 15$ & $70 / 75$ & $175 / 90$ & $74 / 75$ & $205 / 70$ & $262 / 90$ & $120 / 15$ \\
\hline $190 / 75$ & $115 / 85$ & $180 / 85$ & $220 / 90$ & $70 / 80$ & $100 / 90$ & $100 / 75$ & $225 / 60$ & $192 / 65$ & $138 / 85$ \\
\hline $200 / 70$ & $95 / 75$ & $275 / 90$ & $100 / 90$ & $300 / 70$ & $360 / 80$ & $210 / 60$ & $225 / 90$ & $144 / 80$ & $45 / 75$ \\
\hline $160 / 70$ & $100 / 90$ & $290 / 85$ & $75 / 70$ & $230 / 75$ & $200 / 70$ & $280 / 80$ & $10 / 80$ & $250 / 40$ & $60 / 80$ \\
\hline $225 / 40$ & $135 / 80$ & $110 / 80$ & $55 / 40$ & $85 / 70$ & $170 / 70$ & $350 / 75$ & $185 / 90$ & $200 / 30$ & $275 / 45$ \\
\hline $255 / 35$ & $123 / 75$ & $07 / 65$ & $62 / 40$ & $90 / 60$ & $180 / 50$ & $235 / 65$ & $190 / 80$ & $205 / 30$ & $280 / 70$ \\
\hline $215 / 40$ & $340 / 90$ & $100 / 70$ & $57 / 35$ & $215 / 80$ & $205 / 40$ & $340 / 85$ & $205 / 80$ & $230 / 30$ & 10/30 \\
\hline $180 / 70$ & $260 / 80$ & $120 / 80$ & $70 / 60$ & $175 / 85$ & $205 / 50$ & $220 / 70$ & $115 / 70$ & $100 / 85$ & $205 / 85$ \\
\hline $185 / 70$ & $255 / 90$ & $85 / 80$ & $50 / 50$ & $225 / 90$ & $145 / 80$ & $165 / 60$ & $110 / 80$ & $30 / 85$ & $210 / 85$ \\
\hline $210 / 40$ & $265 / 70$ & $240 / 80$ & $245 / 90$ & $180 / 75$ & $210 / 55$ & $220 / 50$ & $130 / 70$ & $235 / 50$ & $265 / 90$ \\
\hline $255 / 45$ & $215 / 65$ & $165 / 90$ & $230 / 75$ & $90 / 80$ & $225 / 25$ & $215 / 85$ & $300 / 50$ & $215 / 35$ & $106 / 70$ \\
\hline $205 / 45$ & 10/85 & $170 / 85$ & $235 / 75$ & $340 / 80$ & $165 / 60$ & $260 / 55$ & $292 / 70$ & $155 / 70$ & $110 / 60$ \\
\hline $212 / 70$ & $350 / 60$ & $275 / 50$ & $270 / 75$ & $345 / 80$ & $185 / 45$ & $270 / 30$ & $264 / 60$ & $265 / 90$ & $20 / 30$ \\
\hline $225 / 40$ & $240 / 90$ & $275 / 90$ & $258 / 80$ & $300 / 90$ & $45 / 45$ & $240 / 35$ & $270 / 80$ & $290 / 85$ & $360 / 30$ \\
\hline $270 / 45$ & $245 / 90$ & $220 / 65$ & $85 / 85$ & $340 / 80$ & $155 / 65$ & $180 / 40$ & $164 / 85$ & $340 / 60$ & $235 / 70$ \\
\hline $245 / 50$ & $330 / 80$ & $248 / 90$ & $255 / 70$ & $70 / 65$ & $280 / 90$ & $180 / 45$ & $212 / 90$ & $360 / 75$ & $215 / 80$ \\
\hline $42 / 45$ & $220 / 65$ & $60 / 90$ & $255 / 85$ & $35 / 90$ & $280 / 80$ & $290 / 85$ & $223 / 85$ & $310 / 90$ & $280 / 85$ \\
\hline $225 / 45$ & $140 / 80$ & $186 / 70$ & $250 / 70$ & $215 / 90$ & $290 / 90$ & $215 / 85$ & $54 / 85$ & $172 / 87$ & $290 / 85$ \\
\hline $232 / 70$ & $150 / 70$ & $220 / 70$ & $180 / 60$ & $165 / 90$ & $245 / 90$ & $230 / 90$ & $140 / 75$ & $192 / 70$ & $40 / 70$ \\
\hline $39 / 20$ & $120 / 80$ & $200 / 70$ & $225 / 75$ & $200 / 60$ & $50 / 35$ & $275 / 80$ & $132 / 90$ & $170 / 80$ & $180 / 40$ \\
\hline $35 / 25$ & $60 / 50$ & $282 / 65$ & $210 / 65$ & $240 / 80$ & $210 / 40$ & $235 / 70$ & $68 / 70$ & $248 / 80$ & $175 / 80$ \\
\hline $215 / 60$ & $310 / 60$ & $75 / 50$ & $210 / 55$ & $235 / 70$ & $145 / 80$ & $185 / 75$ & $280 / 85$ & $246 / 40$ & $255 / 65$ \\
\hline $50 / 20$ & $40 / 17$ & $230 / 70$ & $130 / 70$ & $210 / 75$ & $265 / 80$ & $195 / 70$ & $12 / 80$ & $224 / 35$ & $220 / 70$ \\
\hline $190 / 65$ & $215 / 65$ & $210 / 85$ & $275 / 55$ & $290 / 65$ & $248 / 75$ & $240 / 70$ & $262 / 85$ & $220 / 65$ & $120 / 85$ \\
\hline $195 / 60$ & $325 / 90$ & $200 / 65$ & $85 / 80$ & $205 / 80$ & $210 / 60$ & $295 / 40$ & $170 / 85$ & $270 / 50$ & $125 / 85$ \\
\hline $190 / 25$ & $140 / 85$ & $245 / 60$ & $90 / 85$ & $200 / 90$ & $20 / 70$ & $175 / 60$ & $204 / 65$ & $144 / 45$ & $106 / 87$ \\
\hline $200 / 30$ & $275 / 90$ & $180 / 65$ & $85 / 80$ & $215 / 80$ & $200 / 60$ & $290 / 75$ & $218 / 60$ & $286 / 45$ & $156 / 70$ \\
\hline $245 / 20$ & $165 / 70$ & $210 / 70$ & $245 / 85$ & $135 / 80$ & $285 / 85$ & $265 / 70$ & $140 / 90$ & $238 / 25$ & $260 / 70$ \\
\hline $280 / 70$ & $290 / 90$ & $180 / 55$ & $60 / 85$ & $280 / 80$ & $295 / 90$ & $235 / 60$ & $222 / 60$ & $130 / 85$ & $130 / 85$ \\
\hline $320 / 80$ & $290 / 85$ & $205 / 75$ & $75 / 85$ & $325 / 80$ & $240 / 60$ & $250 / 60$ & $100 / 80$ & $200 / 30$ & $220 / 55$ \\
\hline $105 / 80$ & $115 / 80$ & $205 / 90$ & $100 / 90$ & $285 / 85$ & $210 / 45$ & $260 / 75$ & $45 / 60$ & $220 / 60$ & $152 / 45$ \\
\hline $190 / 65$ & $05 / 70$ & & & & & & & & \\
\hline
\end{tabular}

Quanto à abertura das falhas, a abertura média é de cerca de $2 \mathrm{~cm}$, entretanto, podem ser encontrados casos extremos em que a abertura se encontra entre 10 e $20 \mathrm{~cm}$ (BUREAU 2010). Aberturas maiores são relacionadas a placas instáveis de esfoliação esferoidal, em fase de desplacamento do maciço. A rugosidade observada nos planos de descontinuidades e falhas foi caracterizada de acordo com seu perfil geométrico (Fig. 23), quantificando seu coeficiente de rugosidade da junta (JRC) entre 10 e 16 de acordo com o item 5.4 do Capítulo 4 do presente trabalho.

O preenchimento das aberturas é provavelmente originado do regolito alóctone, solo e matéria orgânica proveniente da parte superior vegetada do morro, sendo as aberturas localmente preenchidas por vegetação de pequeno e médio porte. Não se observa presença de preenchimento por calcita ou sílica.

Bureau (2010) considera coerente adotar ângulo de atrito interno de $45^{\circ}$, nos cálculos de estabilidade de massas de rocha, a partir da caracterização das descontinuidades, e sem admitir presença de volume significativo de água nas mesmas.

\section{Análise de queda de blocos na encosta}

Para se analisar possíveis queda de blocos e/ ou formação de cunhas, foram cruzadas as atitudes preferenciais dos planos de fraturas entre si e 
Tabela 10. Dados de juntas de esfoliação ("casca de cebola")

\begin{tabular}{|c|c|c|c|c|c|c|}
\hline $44 / 55$ & $30 / 40$ & $75 / 45$ & $50 / 45$ & $55 / 55$ & $72 / 55$ & $50 / 40$ \\
\hline $48 / 50$ & $20 / 45$ & $58 / 60$ & $42 / 50$ & $35 / 60$ & $66 / 45$ & $10 / 40$ \\
\hline $45 / 50$ & $15 / 40$ & $66 / 60$ & $50 / 50$ & $40 / 50$ & $60 / 45$ & $25 / 35$ \\
\hline $50 / 50$ & $25 / 30$ & $68 / 50$ & $28 / 40$ & $55 / 65$ & $62 / 50$ & $64 / 55$ \\
\hline $42 / 54$ & $28 / 40$ & $50 / 70$ & $50 / 70$ & $30 / 50$ & $40 / 50$ & $68 / 60$ \\
\hline $220 / 90$ & $30 / 30$ & $48 / 60$ & $55 / 70$ & $80 / 50$ & $60 / 50$ & $30 / 50$ \\
\hline $210 / 90$ & $25 / 50$ & $52 / 60$ & $70 / 75$ & $85 / 55$ & $64 / 50$ & $45 / 40$ \\
\hline $245 / 45$ & $40 / 50$ & $50 / 65$ & $35 / 70$ & $90 / 60$ & $80 / 50$ & $35 / 55$ \\
\hline $204 / 35$ & $40 / 45$ & $58 / 60$ & $40 / 60$ & $100 / 75$ & $80 / 45$ & $64 / 45$ \\
\hline $228 / 60$ & $75 / 55$ & $58 / 40$ & $65 / 50$ & $65 / 35$ & $78 / 45$ & $64 / 40$ \\
\hline $230 / 50$ & $85 / 55$ & $60 / 40$ & $35 / 45$ & $60 / 50$ & $84 / 50$ & $56 / 60$ \\
\hline $15 / 55$ & $65 / 70$ & $64 / 40$ & $55 / 50$ & $75 / 60$ & $78 / 55$ & $38 / 40$ \\
\hline $358 / 40$ & $55 / 55$ & $62 / 45$ & $30 / 40$ & $110 / 60$ & $85 / 45$ & $26 / 45$ \\
\hline $05 / 35$ & $70 / 50$ & $60 / 40$ & $35 / 45$ & $60 / 50$ & $84 / 50$ & $20 / 60$ \\
\hline $08 / 40$ & $70 / 50$ & $64 / 60$ & $40 / 50$ & $80 / 50$ & $82 / 55$ & $25 / 45$ \\
\hline $10 / 90$ & $70 / 45$ & $70 / 60$ & $05 / 55$ & $75 / 50$ & $72 / 50$ & $72 / 55$ \\
\hline $20 / 50$ & $60 / 80$ & $36 / 45$ & $50 / 60$ & $85 / 40$ & $80 / 55$ & $84 / 65$ \\
\hline $16 / 50$ & $50 / 60$ & $42 / 50$ & $60 / 50$ & $80 / 50$ & $68 / 65$ & $60 / 65$ \\
\hline $20 / 45$ & $50 / 55$ & $44 / 35$ & $30 / 50$ & $60 / 45$ & $70 / 55$ & $60 / 55$ \\
\hline $10 / 40$ & $75 / 60$ & $70 / 65$ & $25 / 60$ & $80 / 45$ & $66 / 65$ & $28 / 50$ \\
\hline $60 / 70$ & $66 / 57$ & $60 / 75$ & $35 / 50$ & $90 / 60$ & $68 / 50$ & $38 / 45$ \\
\hline $85 / 75$ & $65 / 45$ & $14 / 55$ & $50 / 50$ & $80 / 55$ & $68 / 55$ & $50 / 45$ \\
\hline $90 / 65$ & $65 / 45$ & $28 / 45$ & $40 / 60$ & $35 / 40$ & $75 / 45$ & $64 / 60$ \\
\hline $334 / 80$ & $65 / 40$ & $32 / 50$ & $40 / 55$ & $10 / 40$ & $70 / 50$ & $27 / 55$ \\
\hline $355 / 55$ & $50 / 45$ & $30 / 55$ & $40 / 50$ & $20 / 35$ & $44 / 50$ & $02 / 55$ \\
\hline $10 / 50$ & $52 / 45$ & $52 / 50$ & $55 / 35$ & $50 / 60$ & $58 / 55$ & $25 / 60$ \\
\hline $360 / 70$ & $55 / 45$ & $34 / 45$ & $40 / 50$ & $45 / 55$ & $56 / 55$ & $82 / 60$ \\
\hline $38 / 40$ & $60 / 50$ & $32 / 60$ & $45 / 40$ & $50 / 40$ & $70 / 50$ & $75 / 50$ \\
\hline $12 / 45$ & $45 / 50$ & $24 / 45$ & $50 / 40$ & $55 / 50$ & $15 / 60$ & $36 / 50$ \\
\hline $15 / 30$ & $55 / 45$ & $13 / 50$ & $35 / 60$ & $65 / 60$ & $20 / 60$ & $50 / 40$ \\
\hline $05 / 40$ & $50 / 50$ & $360 / 40$ & $60 / 50$ & $50 / 55$ & $20 / 65$ & $25 / 50$ \\
\hline
\end{tabular}

com relação à orientação da vertente. Nota-se que nenhuma cunha é formada pelas descontinuidades no rumo de mergulho da vertente, uma vez que a intersecção dos planos se dá no interior do maciço, sem representar perigo para a estabilidade da encosta (Fig. 24). Em relação aos dados de juntas de esfoliação, fica visível que blocos formados pelas juntas tendem a se tornar instáveis, uma vez que apresentam mergulho maior que a vertente. Deve-se ressaltar que o ângulo de atrito interno não faz parte da figura, uma vez que o valor de $45^{\circ}$ é maior do que a inclinação da vertente. No presente trabalho a vertente foi considerada com mergulho constante, sem levar em conta pequenas variações de inclinação. Caso os dados fossem discriminados em zonas de análise, talvez fosse viável fazer análise estrutural detalhada de cada parte isolada do maciço.

Uma vez que somente blocos de rochas formados por juntas de esfoliação são instáveis na vertente do Morro Santa Terezinha, Bureau (2010) sugeriu a retirada dos blocos instáveis de menor volume, numerados de 1 a 8 na figura 25. Lajes de maior volume serão tratadas com tirantes e a frente da vertente com chumbadores, isso evitará o deslocamento de blocos e consequente instabilidade devido à alteração. 

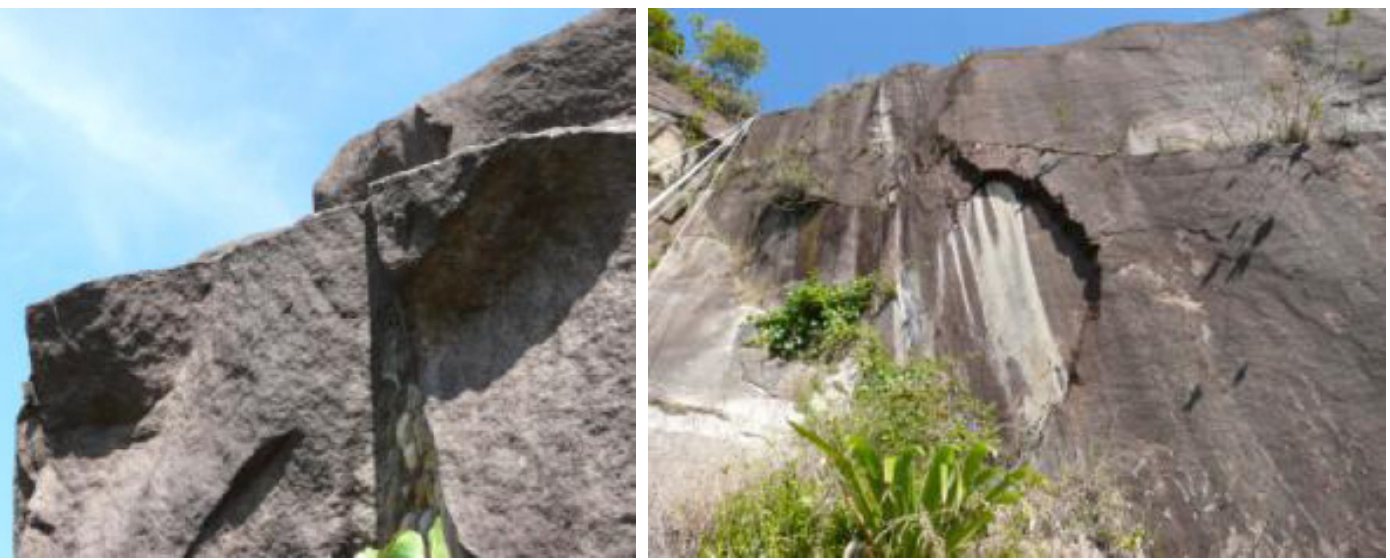

Figura 23. Rugosidades típicas das descontinuidades do maciço

\section{Um método de análise de queda de blocos em encostas}

Com apoio nos conceitos sobre fraturamento e geometria de maciços rochosos, nos procedimentos de coleta e nos critérios de interpretação de dados estruturais expostos em capítulos anteriores, pode-se afirmar que, em áreas de risco, qualquer levantamento estrutural deve contemplar o estudo e registro dos parâmetros listados abaixo (Ramsay e Huber 1987):

- Orientação das fraturas.

- Espaçamento/frequência, extensão.

- Persistência.

- "Aspecto": planaridade relativa e rugosidade relativa.

- Grau de abertura e material de preenchimento.

- Interrelação de diferentes sistemas de juntas.

Levantamentos estruturais podem ser lentos ou expeditos, dependendo da extensão da área, da escala de abordagem e do grau de detalhamento exigido pelas aplicações. Assim, a abordagem de cada situação específica deve ser cuidadosamente planejada. A execução das medidas por rapel pode garantir acesso a porções fortemente inclinadas da encosta, onde se expõem rochas inalteradas ou pouco alteradas. Neste exemplo, a técnica possibilitou determinar a orientação e as características de sistemas de juntas de esfoliação que não haviam sido reconhecidas nem caracterizadas com tanto detalhe em trabalhos anteriores.

O procedimento de escalada por rapel adotado pela empresa Bureau (2010) para mapear estruturas do Granito Santos pode ser considerado exemplar, porque, diante de uma situação de risco potencial para os geólogos envolvidos, inexperientes em relação à técnica, uma equipe
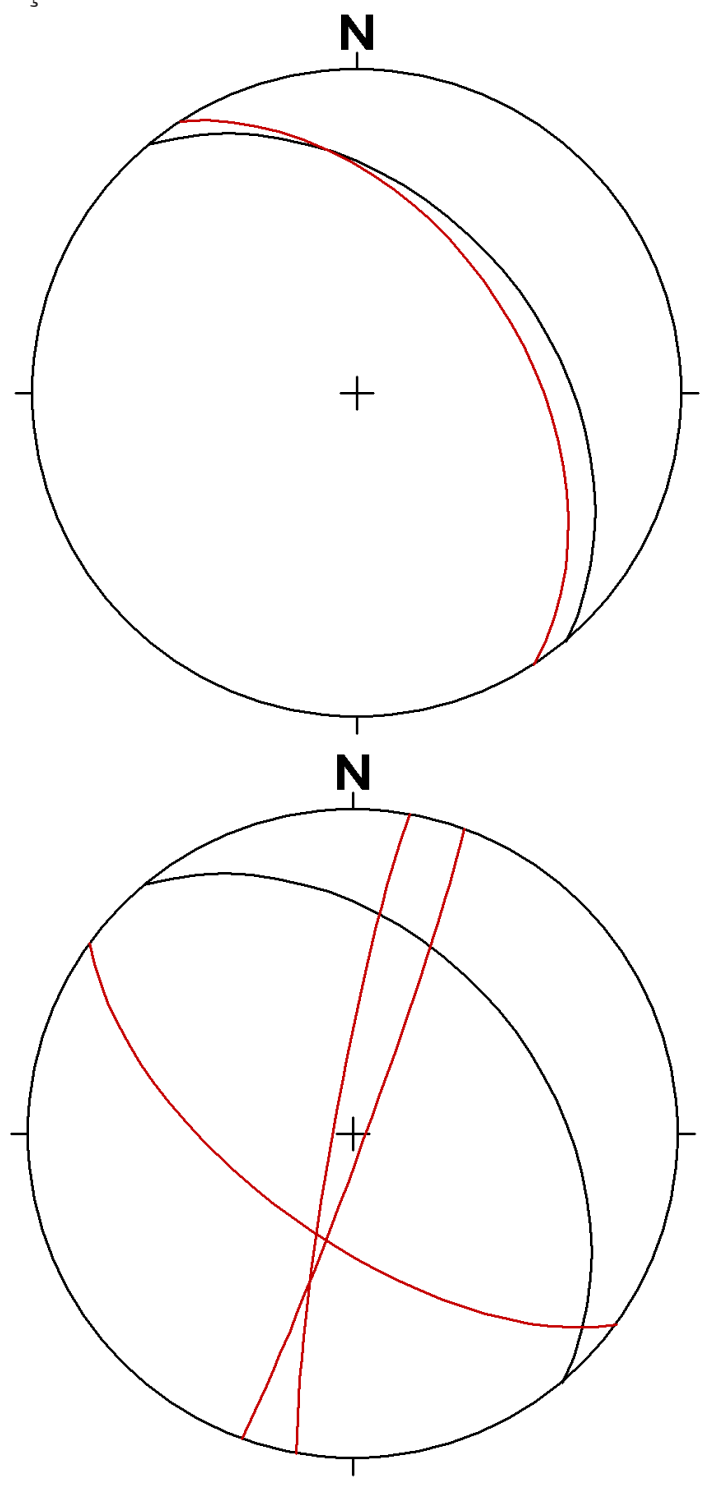

Figura 24. Presença de blocos instáveis na vertente devido a juntas de esfoliação (a), vertente estável e sem formação de cunhas devido à interações de falhas e fraturas (b) 


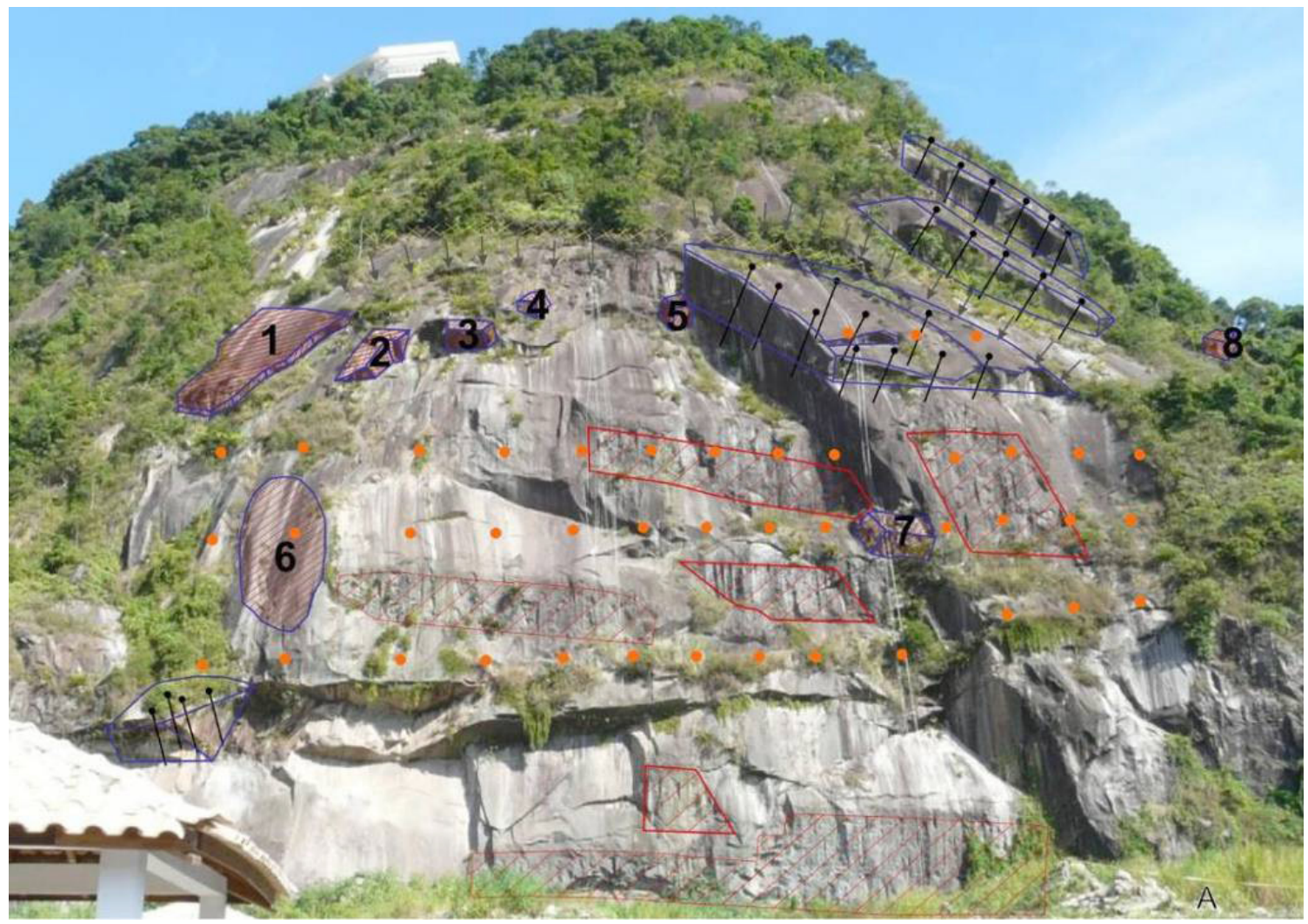

Figura 25. Vista geral da exposição a partir da base. A extensão total do corte é de aproximadamente $100 \mathrm{~m}$. 0 tratamento sugerido para a encosta do Morro Santa Terezinha inclui remoção física dos blocos de rocha instáveis, uso de tirantes nas lajes de rocha e chumbadores na parede da vertente (Fonte: Bureau 2010)

especializada garantiu a infraestrutura e supervisionou o trabalho. Essa ressalva é essencial para evitar a possível repetição autônoma e indevida do procedimento.

A conclusão de Ribeiro et al. (2009b) de que, dentre os movimentos de massa, a queda/ rolamento de blocos é o fenômeno que oferece a maior dificuldade para previsão do início de deslizamentos e movimentações, revela um componente essencial: a condição necessária para incidência do fenômeno pode ser a existência de uma única fratura com orientação desfavorável na encosta. Isso torna ainda mais remota a possibilidade de se efetuar previsões adequadas em áreas extensas, como as regiões serranas que dominam grande parte das porções costeiras do sudeste brasileiro. Dessa forma, a análise estrutural de áreas de risco em zonas formadas por rochas ígneas desprovidas de estruturas penetrativas outras que não as fraturas, deveria combinar, por um lado, os métodos convencionais de análise e coleta de dados para tratamento e avaliação estatística de populações de descontinuidades presentes e, por outro lado, ser suficientemente pormenorizada a ponto de contemplar a situação específica de qualquer junta de esfoliação ou outro tipo de fratura que possa oferecer risco potencial.

A identificação visual de juntas de esfoliação é em geral impossibilitada pela existência de vegetação de pequeno a médio porte nas encostas. Assim, novos desenvolvimentos deveriam ser perseguidos no campo da investigação geofísica. O aperfeiçoamento da determinação de certos parâmetros pode ajudar a delimitar a extensão, orientação e grau de abertura de juntas de esfoliação.

\section{Conclusões}

A revisão metodológica possibilitou sintetizar os principais conceitos e técnicas que devem ser empregados em mapeamentos estruturais de encostas em áreas de risco. A aplicação da técnica de rapel para coleta de dados estruturais em encosta de alta declividade permitiu, no Morro Santa Terezinha, dentro de condições controladas para garantir a segurança dos geólogos envolvidos, obter resultados críticos para avaliação de risco de escorregamentos, desplacamentos e queda de blocos. 
O método empregado na regionalização de dados estruturais no maciço rochoso dos Morros de Santos e São Vicente, disponível na literatura-base, também revelou-se altamente eficiente para caracterizar tendências do fraturamento.

Estudos geológico-estruturais recentes acentuam a importância das juntas de esfoliação como feições capazes de promover, em virtude da desagregação intempérica gradual, o progressivo isolamento de massas de rocha, que podem se desprender e escorregar encosta abaixo.

Uma ressalva que deve ser feita ao método aqui sintetizado é a de que a presença de uma única fratura com orientação desfavorável na encosta pode ser suficiente para provocar um acidente geológico, de certo modo, tal constatação é contrária ao caráter essencialmente estatístico da abordagem intrínseca à análise estrutural.

Uma das principais conclusões do trabalho é, portanto, que a análise estrutural de áreas de risco deve combinar, ao mesmo tempo, a avaliação estatística de populações de descontinuidades presentes mas precisa contemplar, a mesmo tempo, a situação específica de cada fratura que possa oferecer risco potencial. A ressalva metodológica é essencial, porque o geólogo que realiza estudos estruturais em áreas de encostas e taludes deve estar atento para pormenores do maciço, como uma descontinuidade isolada, ao mesmo tempo em que busca coletar um conjunto de informações acerca dos padrões locais/ regionais de fraturamento. Se for dada demasiada importância para o modelo regional, ou vice-versa, algum aspecto estrutural relevante pode ser ignorado, diminuindo a possibilidade de prever eventuais acidentes, por deficiências do levantamento.

A reanálise estatística de dados confirma, até certo ponto, o modelo proposto por Bureau (2010): a população de dados amostrados no campo indica forte concentração espacial das juntas de esfoliação e a existência de dois outros sistemas. O sistema de juntas de esfoliação possui direção média N30W e mergulhos entre $40^{\circ}$ e $50^{\circ}$, um dos sistemas de fraturas possui direção média N60W e mergulhos entre $60^{\circ}$ e $70^{\circ}$, enquanto o outro sistema tem campo de variação direcional entre N10E e N20E e mergulhos verticais.

Uma vez catacterizadas as famílias principais de fraturas, é viável realizar análise de formação de cunhas, pelo cruzamento das atitudes preferenciais dos planos de fraturas entre si e com relação à orientação da vertente. Nenhuma cunha favorável ao rumo de mergulho da vertente é formada pelas descon- tinuidades no presente caso, porque os planos são muito inclinados, até subverticais, e se interseptam no interior do maciço. Excetuadas as importantíssimas juntas de esfoliação, não parece existir no Morro Santa Terezinha outro arranjo estrutural que ofereça risco significativo à estabilidade da encosta.

\section{Referências}

Almeida F.F.M.de. 1986. Distribuição regional e relações tectônicas do magmatismo pós-paleozóico no Brasil. Rev. Bras. Geoc., 16(4):325-349.

Amaral C. 2009. Gestão do risco a escorregamentos no Estado do Rio de Janeiro. In: Simpósio de Geologia do Sudeste, 11, São Pedro, 2009. Anais... São Paulo: Sociedade Brasileira de Geologia, Núcleos de São Paulo, Rio de Janeiro / Espírito Santo e Minas Gerais. p. 147.

Augusto Filho O., Virgili J.C. 1998. Estabilidade de taludes. In: Oliveira A.M.S, Brito S.N.A. (ed.) Geologia de Engenharia. São Paulo: Associação Brasileira de Geologia de Engenharia (ABGE). p 243-269.

Barton N., Choubey V. 1977. The shear strength of rock joints in theory and practice. Rock Mech., 10(1-2):1-54.

Bradley W.C. 1962. Large-scale exfoliation in massive sandstones of the Colorado Plateau. Geol. Soc. Am. Bull., 74:519-528. URL: http://bulletin.geoscienceworld.org/cgi/content/abstract/74/5/519. Acesso: 12.01.2011.

Brollo M.J., Ferreira C.J. 2009. Indicadores de desastres naturais no Estado de São Paulo. In: Simpósio de Geologia do Sudeste, 11, São Pedro, 2009. Anais... São Paulo: Sociedade Brasileira de Geologia, Núcleos de São Paulo, Núcleos Rio de Janeiro / Espírito Santo e Minas Gerais. p. 125.

Brown E.T. (ed.) 1981. Rock characterization testing and monitoring: ISRM suggested methods. Oxford: Pergamon Press. 211p.

Buckingham D., Carter M., Damman R., Hung O., Kennedy P., Monta D. s.d. Yosemite National Park. How Can We Help? URL: http://wildernessexp1-fa10.wikispaces.com/Group+One. Acesso: 21.05.2013.

Bureau de Projetos e Consultoria Ltda. (Bureau) 2010. Contenção da Encosta Nordeste do Morro Santa Terezinha, Santos, Baixada Santista, SP. São Paulo, Bureau de Projetos e Consultoria Ltda. (Rel. RC_08509_2010-03-04_Preliminar.pdf).

Carneiro C.D.R. (coord.) 1996. Projeção estereográfica para análise de estruturas. Programas ESTER e TRADE. Fundamentos Teóricos, Exercícios e Aplicações em Microcomputador, Laboratório e Campo. Campinas: Co-edição CPRM / IG-Unicamp / IPT-DIGEO. 184p. (CPRM / IG-Unicamp / IPT, Livro). 
Carneiro C.D.R. 1983. Análise estrutural do Grupo São Roque na faixa entre o Pico do Jaraguá e a Serra dos Cristais, SP. São Paulo. 155p. (Tese dout. Inst. Geoc. USP).

Carneiro C.D.R., Pinotti A.M. 2011. Juntas de esfoliação: um problema estrutural das encostas do Morro de Santa Terezinha, entre Santos e São Vicente, SP. In: simp. Nac. Est. Tectônicos, 13, Campinas, 2011 e intern. Simp. on tectonics, 7, Recife, 2011. Anais VIII SNET..., Campinas: SBG/NE. (CDROM, 532-ST5.PDF)

Carneiro C.D.R., Pinotti A.M. 2012. Geologia Estrutural na previsão de quedas e contenção de blocos em encostas do Granito Santos, Santos, SP. In: Congr. Bras. Geol., 46, Santos, 2012. Resumos... Santos, SBGeo. CD-ROM 46CBG, PAP010555. (Simp. Tem. "Geologia de Engenharia, Ambiental e Planejamento").

Carneiro C.D.R., Santoro E., Rodrigues E.P., Hasui Y. 1979. Evolução Geológica do Pré Cambriano da Baixada Santista. In: Simpósio Regional de Geologia, 2, Rio Claro, 1979. Atas... Rio Claro: Sociedade Brasileira de Geologia, Núcleo São Paulo. v. 1, p. 31-46.

Carvalho I.R.T.V.de, Corrêa A.C.B. 2009. Contribuição da geomorfologia na recuperação de áreas submetidas a processos erosivos resultantes da reabilitação da estrada São Domingos/Assomada, Cabo Verde, África Ocidental In: Simp. Nac. Contr. Erosão, 11, 2009, São Paulo. Anais... São Paulo: ABGE, 2009. (CD-ROM).

Carvalho P.A.S. (Coord.). 1991. Talude de rodovias: orientação para diagnóstico e soluções de seus problemas. São Paulo: IPT. 410p. (Publ., 1843).

Christofoletti A. 1999. Modelagem de sistemas ambientais. $2^{a}$ reimpr. 2002. São Paulo: Blücher/EDUSP. 236p.

Copons Llorens R., Tallada Masquef A. 2009. Movimientos de ladera. Rev. de la Enseñanza de las Ciencias de la Tierra. 17(3):284-294.

Fiori A. P., Carmignani L. 2009. Fundamentos de mecânica dos solos e das rochas: aplicações na estabilidade de taludes. 2.ed. Curitiba: Ed. UFPR. 604p.

Fiori A.P. 1997. Introdução à Análise da Deformação. Curitiba: Ed. UFPR. 249p.

Guidicini G., Nieble C.M. 1976. Estabilidade de taludes naturais e de escavação. Editora Edgard Blücher Ltda, São Paulo, 170 p.

Hancock P.L., Engelder T. 1989. Neotectonic joints. GSA Bulletin, 101(10):1197-1208. DOI: 10.1130/0016-7606(1989)101<1197:NJ>2.3 .CO;2 URL: http://bulletin.geoscienceworld. org/cgi/content/abstract/101/10/1197. Acesso 26.01.2011.

Harland W.B. 1957. Exfoliation joints and ice action. J. Glaciol., 3(21):8-10.

Hasui Y., Mioto J.A. 1992. Geologia Estrutural Aplicada. São Paulo: ABGE, Votorantim. 459p.
Hasui Y., Sadowski G.R. 1976. Evolução geológica do pré-cambriano na região sudeste do Estado de São Paulo. Rev. Bras. Geoc., 6:182-200.

Hobbs B.E., Means W.D., Williams P.F. 1976. An outline of structural geology. New York: John Wiley. 571p.

Hoek E. 2007. Practical rock engineering. S.L.. 237p. URL: http://download.rocscience.com/hoek/ PracticalRockEngineering.asp. Acesso 27.01.2011.

Hoek E., Bray J. 1981. Rock slope engineering. 3 ed. London: IMM. 527p.

Hoek E., Londe P. 1974. Surface workings in rock. In: International Congress on Rock Mechanics, 3, 1974, Denver. Proc... Washington: National Academy of Sciences. v. 1, p. 613-654.

IAEG. 1981. Rock and soil description and classification for engineering geological mapping. IAEG Bull., (24):235-274.

Infanti Jr., N, Fornasari Fo. N. 1998. Processos de dinâmica superficial. In: Oliveira A.M.S, Brito S.N.A. Geologia de Engenharia. São Paulo: Assoc. Bras. Geol. Engenharia (ABGE). p 131-152.

Instituto de Pesquisas Tecnológicas do Estado de São Paulo. IPT. 1980. Seleção e arpimoramento de metodologias para a regionalização de dados de fraturamento de maciços rochosos. São Paulo: IPT. 54p. (IPT, Rel. Técn., 13.229).

International Society for Rock Mechanics, ISRM. 1983. Método para descrição quantitativa de descontinuidades em maciços rochosos. Trad. de : ISRM. Suggested methods for the quantitative description of rock masses. São Paulo: ABGE/CBRM 132p. (Trad. 12).

Instituto de Pesquisas Tecnológicas do Estado de São Paulo. IPT. 1984. Estudos geológico-geotécnicos para caracterização e classificação de maciços rochosos para projetos de engenharia (túneis, lavra a céu aberto e barragens). São Paulo. IPT. (Rel., 19.569).

Jahns R. H. 1943. Sheet structure in granites, its origin and use as a measure of glacial erosion in New England. J. Geol., 51:71-98.

Knapp B.J., Ross S.R.J., Crae D.L.R.Mc. 1991. Challenge of the Natural Environment. Essex: Longman, $272 \mathrm{p}$.

Legrand H.E. 1949. Sheet structure, a major factor in the occurrence of ground water in the granites of Georgia. Econ. Geology, 44:110-118. URL: http://econgeol.geoscienceworld.org/cgi/ reprint/44/2/110.pdf. Acesso: 12.01.2011.

Leyshon P.R., Lisle R.J. 1996. Stereographic projection techniques in Structural Geology. Oxford: ButterworthHeinemann, 104p.

Lisle R.J. 1995. Geological structures and maps. 2 ed. Oxford: Butterworth-Heinemann. 104p.

Llorente Isidro M., Laín Huerta L. 2009. Riesgos geológicos: técnicas de análisis y mitigación. Rev. de la Enseñanza de las Ciencias de la Tierra. 17(3):232- 
241.

Loczy L.de, Ladeira E.A. 1976. Geologia Estrutural e introdução à Geotectônica. São Paulo: Blücher/CNPq. $528 \mathrm{p}$.

Magalhães F.S., Cella P.R.C. 1998. Estrutura dos maciços rochosos In: Oliveira A.M.S, Brito S.N.A. Geologia de Engenharia. São Paulo: Associação Brasileira de Geologia de Engenharia (ABGE 1998), p. 39-55.

Markland J.T. 1972. An useful technique for estimating the stability of rock slopes when the ridge wedge sliding type of failure is expected. Imperial College Rock Mech. Research Report, n.19, 10p.

Martel S.J. 2006. Effect of topographic curvature on near-surface stresses and application to sheeting joints, Geophys. Res. Lett., 33, L01308, doi:10.1029/2005GL024710. Acesso: 12.01.2011.

Müller L. 1963. Der Felsbau. Enke Ferlag.

Nelson S.A. 2003. Mass-wasting. Physical Geology. Course on Earth \& Environmental Sciences. Tulane University. URL: http://www.tulane. edu/ sanelson/geol111/masswasting.htm. Acesso 3.12.2010

Neves M.A., Morales N. 2001. Análise de paleotensores e neotectônica na região de Jundiaí (SP). In: Simpósio Nacional de Estudos Tectônicos, 8, 2001, Recife. Anais... São Paulo: SBG, 2001. p. 339-341.

Park R.G. 1991. Foundations of Structural Geology. New York: Blackie \& Son / Chapman and Hall. 148p.

Pichler E. 1957. Aspectos geológicos dos escorregamentos de Santos. Bol. Soc. Bras. Geol., São Paulo, 6(2):69-77

Pinotti A.M. 2011. Técnicas de Geologia Estrutural para previsão e contenção de queda de blocos em encostas: aplicação na área do Granito Santos, Santos, SP. Campinas: IG-Unicamp. (Trab. Concl. Curso Grad. Geologia).

Pires Neto A.G., Ponçano W.L., Carneiro C.D.R., Stein D.P. 1979. Carta Geomorfológica dos Morros de Santos e São Vicente, SP. In: Simpósio Regional de Geologia, 2, Rio Claro, 1979. Atas... Rio Claro: Sociedade Brasileira de Geologia, Núcleo de São Paulo. v. 2, p. 279-290.

Porto Jr. R., Antunes F.A., Amaral C. 2005. Controle geológico-estrutural nos escorregamentos na cidade do Rio de Janeiro, RJ, Brasil. In: Simpósio de Geologia do Sudeste, 9, Niterói, 2005. B. Resumos... Niterói: Sociedade Brasileira de Geologia, Núcleos Rio de Janeiro / Espírito Santo, Minas Gerais e São Paulo. p. 120.

Prandini F.L., Carneiro C.D.R., Pires Neto A.G., Iwasa O.Y., Ponçano W.L., Santos A.R.dos, Oliveira A.M.S., Pedrosa G.A., Santos M.C.S.R.dos. 1980. Carta Geotécnica dos Morros de Santos e São Vicente. São Paulo: IPT. 31p. (IPT, Monografias 3).

Quadros E.F. 1992. A condutividade hidráulica direcional de maciços rochosos. São Paulo: EPUSP. 2v. (Tese Dout.).
Ragan D.M. 1973. Structural Geology, an introduction to geometrical techniques. 2 ed. New York: John Wiley. 208 p.

Ramsay J.C., Huber M.I. 1987. The techniques of modern structural geology. London: Academic Press. p. 308700. (v. 2: Folds and Fractures).

Ribeiro R.S., Barroso E.V., Borges A.F. 2009a. Análise de parâmetros relativos a queda/rolamento de blocos rochosos em uma encosta ocupada no município de Petrópolis (RJ). In: Simpósio de Geologia do Sudeste, 11, São Pedro, 2009. Anais... São Paulo: Sociedade Brasileira de Geologia, Núcleos de São Paulo, Núcleos Rio de Janeiro / Espírito Santo e Minas Gerais. p. 120.

Ribeiro R.S., Barroso E.V., Borges A.F. 2009b. Determinação da área suscetível a ocorrência de queda/ rolamento de blocos utilizando o software PFC-2D no município de Petrópolis (RJ). In: Simpósio de Geologia do Sudeste, 11, São Pedro, 2009. Anais... São Paulo: Sociedade Brasileira de Geologia, Núcleos de São Paulo, Rio de Janeiro / Espírito Santo e Minas Gerais. p. 121.

Ruhland M. 1973. Méthode d'étude de la fracturation naturelle des roches associée à divers modéles structuraux. Sci. Geól. Bull.. 26(2-3):91-113.

Santana M.A., Mattos J.T.de, Ohara T. 2003. Zonas de movimento de massa na Serra do Mar: uma abordagem morfo-tectônica com imagem Landsat/TM. In: Simpósio de Geologia do Sudeste, 8, São Pedro, 2003. Anais... São Paulo: Sociedade Brasileira de Geologia, Núcleos de São Paulo, Rio de Janeiro / Espírito Santo e Minas Gerais. p. 108.

Santoro E., Carneiro C.D.R., Hasui Y. 1979. Análise Geométrica do fraturamento nos morros de Santos e São Vicente. In: Simpósio Regional de Geologia, 2, Rio Claro, 1979. Atas... Rio Claro: Sociedade Brasileira de Geologia, Núcleo de São Paulo. v. 2, p. 1-12.

Serra E. JR., Ojima L.M. 1998. Caracterização e classificação de maciços rochosos. In: Oliveira A.M.S., Brito S.N.A. Geologia de Engenharia. São Paulo: Associação Brasileira de Geologia de Engenharia (ABGE). p 211-226.

Strahler A.N. 1952. Dynamic basis of geomorphology. Bull. Geol. Soc. Am., 63:923-938.

Terzaghi K. 1967. Mecanismo dos escorregamentos de terra. Publ./ Escola Politécnica USP, 41pp., il. Transcr. Rev. Politécnica (167), jul./ago. 1952. Trad. E. Pichler. T. Orig.: Mechanism of landslides. 1950. Harvard, Dept. Eng., publ. (488):83-123. jan. 1951. (Harvard Soil Mechanics Series 36). Reimpr. por Eng. Geology (Berkey), Vol. Geol. Soc. Am., nov. 1950.

Turner F.J., Weiss L. E. 1963. Structural analysis of metamorphic tectonites. New York, McGraw-Hill Book Co. 545 p. 